\title{
How to Read and Reconstruct a Herculaneum Papyrus*
}

Richard Janko

University of Michigan, USA

There is no simple, practical guide in English to the mechanics of reading and reconstructing the carbonized papyrus-rolls from Herculaneum. ${ }^{\mathrm{I}}$ Literally hundreds of texts await the application of the methods of reading and reconstruction that have been developed since the I980s, not to mention the approximately 280 rolls or parts thereof that may soon become legible by the use of high-energy rays (Figure I). ${ }^{2}$ However, few scholars have had the courage or hardihood to undertake this arduous but extraordinarily rewarding work, which offers our best hope of obtaining new texts from antiquity; hence I have often been asked to record these principles in writing so that they are better known. The reconstruction of the carbonized Derveni papyrus necessarily follows the same principles. ${ }^{3}$ Part I will discuss how to read such papyri; even this is not as simple as it sounds. Part II will review how to reconstruct whole volumina from Herculaneum; several aspects of this will be useful for the reconstruction, whether actual or digital, of non-carbonized papyrus-rolls. ${ }^{4}$

This paper was given on 28 April 2014 at Stockholm University.

* I thank Denis Searby for his kind invitation to Stockholm and the other participants at the seminar, and Justin Barney for reading a draft of this article. I also presented versions of this material the previous week at the University of the Peloponnese, Kalamata, where I thank Prof. Georgia Xanthaki-Karamanou, and at the University of Athens, at a seminar at American Philological Association Annual Meeting in Philadelphia in 2012 (jointly with J. Fish), and at the Center for the Tebtunis Papyri, University of California, Berkeley, in 20I I. All figures marked 'B.N.N.' are reproduced by courtesy of the Ministero per i Beni è le Attività Culturali, Italy (copyright, all rights reserved).

How to cite this book chapter:

Janko, R. 20I 6. How to Read and Reconstruct a Herculaneum Papyrus. In: Crostini, B., Iversen, G. and Jensen, B. M. (eds.) Ars Edendi Lecture Series, vol. IV. Pp. II7-I6I. Stockholm: Stockholm University Press. DOI: http://dx.doi.org/Io.I6993/baj.f. License: CC-BY 4.0 


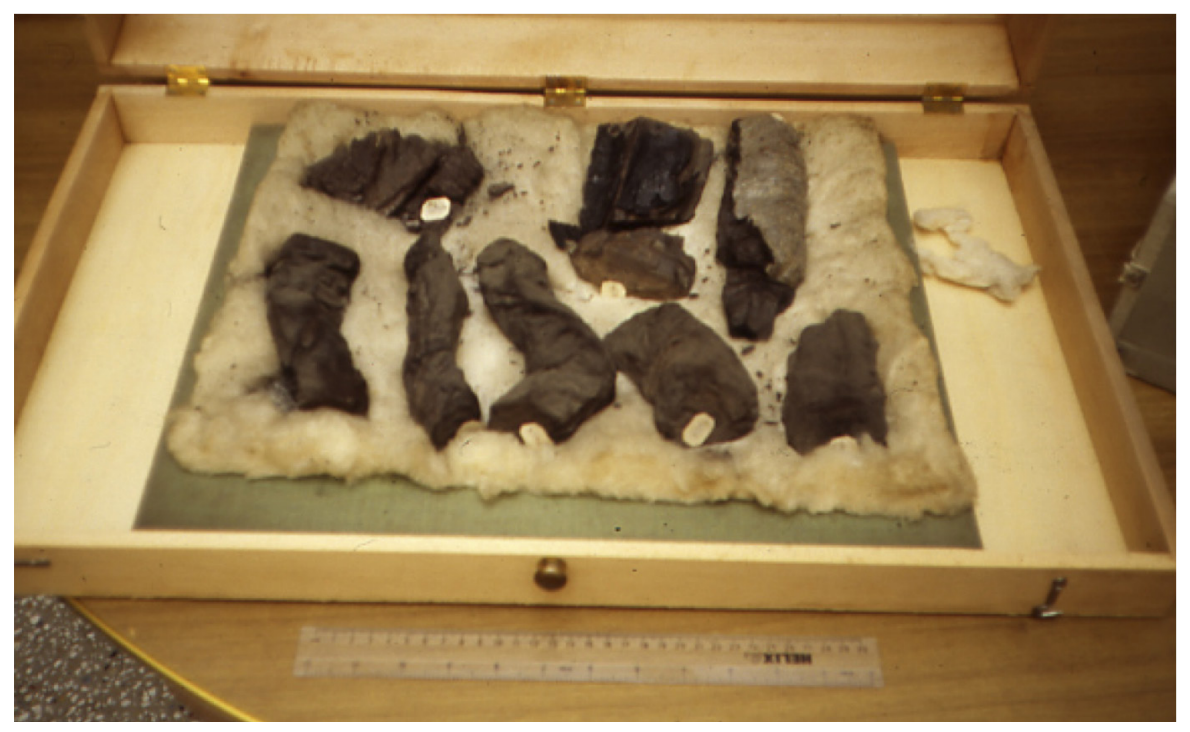

Figure 1. Unopened papyrus-rolls from Herculaneum (photo R. Janko/B.N.N., copyright, all rights reserved)

Any qualified person can study a Herculaneum papyrus upon application to the Soprintendente of the Officina dei Papiri at the Biblioteca Nazionale di Napoli, but the conservators rightly require academic credentials and letters of introduction. The Cronache Ercolanesi publishes annually a list of which scholars are working on which papyri; ${ }^{5}$ it is only proper that access to them should be controlled, so that years of work by one scholar are not duplicated or preempted by the premature publication of an interloper. On the other hand, as is true of all collections of papyri, if for many years or even decades scholars give no sign of working on a text which has been assigned to them, it should eventually be transferred to someone who will bring it out. There is, regrettably, no internationally agreed statute of limitations, to prevent the fortunate (or the greedy) from hoarding papyri and depriving the next generation of the opportunity to make their own discoveries. Shame or loss of reputation seem not to be effective sanctions. The allocation of papyri is among the tasks of the Consiglio of the Centro Internazionale per lo Studio dei Papiri Ercolanesi (CISPE), to whom all researchers should write. ${ }^{6}$ Decisions are taken by the Biblioteca, which is in regular consultation with the CISPE.

The location of particular papyri and disegni within the Officina is recorded in catalogues produced by its recent Superintendents, ${ }^{7}$ which give much other helpful information about these artefacts. These catalogues 
are not to be confused with the Catalogo dei Papiri Ercolanesi, ${ }^{8}$ produced by the CISPE (as are its successive updates ${ }^{9}$ ), which is the indispensable starting-point and lists exhaustively references to each papyrus in published sources. Note, however, that this work often repeats Domenico Bassi's inaccurate and outdated deductions about the history of the unrolling of any particular papyrus. The catalogue of the copious Archive of the Officina is also kept there. A card catalogue gives access to the publications held there, which include copies of nearly every printed item on the Herculaneum papyri that has ever appeared. A computer gives access to the digitized MSI images. ${ }^{\text {Io }}$

\section{Reading the Papyrus}

Most of the papyri from Herculaneum are not conserved between glass, since this would crush the delicate fibres of these carbonized rolls. Instead, they were unrolled and held together with a backing of gold-beater's skin (battiloro). ${ }^{\mathrm{II}}$ This is visible as a wispy grey film behind the papyrus, or stretched across the gaps where it has perished. Its presence is sometimes a useful proof that fragments were in a given spatial relationship, but this impression can also be deceptive. The rolls were cut during unrolling into pieces about $30 \mathrm{~cm}$ wide, which were lightly glued at their corners to a backing sheet of thicker paper (cartoncino). Since the I970s each segment (cornice) has been stored flat, in frames with a transparent lid, from which they are removed for reading. ${ }^{\text {I2 }}$ If the cartoncino is white, coarse, attached with drawing pins to a thin wooden board, and signed with the name 'Conforti', the artisan who did the pinning for Domenico Bassi in the I9Ios, it is an original cartoncino, which may bear precious annotations in ink such as the date of unrolling, the identity of the unroller and the number of the cornice, given as a large letter of the alphabet. If the cartoncino is white or blue and glued to a cardboard backing, it dates from the remounting of the papyri in the I 860 s, when those papyri judged worthy of display were framed and hung up on the walls of the Archaeological Museum. ${ }^{\text {I3 }}$ The latter classes of cartoncini may have had their original numbers changed during remounting, and their corners must be scrutinized for signs of a prior numeration in pencil; to establish the original numbers will require measurement of the sezioni (see Part II). In the I9Ios Bassi either discarded the old cartoncini or turned them over and reused them for mounting other papyri. ${ }^{\mathrm{I}}$

In the I960s Anton Fackelmann separated the layers of other fragments and remounted them onto blotting-paper between sheets of 
glass, ${ }^{15}$ using much the same methods that he applied to the Derveni papyrus. ${ }^{16}$ These are almost impossible to read by eye without lifting the upper sheet of glass, which cannot be lowered again without crushing the papyrus badly (this applies to the Derveni papyrus too). Hence such papyri must be read either from images carefully photographed with an oblique light-source or, to far better effect, through a small digital microscope with a cold light-source which is in almost direct contact with the glass; ${ }^{17}$ otherwise the reflections are just as impossible as with the naked eye, and mean that one can hardly even keep one's gaze on the same place. These are the only papyri in the collection that are deteriorating rapidly, because their fibres have been crushed; this confirms that the old system for conserving carbonized papyri that are curved and/or corrugated is better than mounting them between glass. Pieces obtained by the Kleve-Fosse method of dismantling papyri are again mounted on rice-paper, not under glass, and are stored flat in trays like the older papyri. ${ }^{18}$

Our ability to read carbonized papyri depends in the first instance on our eyes; these must be good. An excellent student of mine, who misread papyri badly because of an astigmatism, read them far better when I suggested that he do so with one eye closed; I suffer myself from a milder version of the same disability, which makes it difficult to see depth and therefore to distinguish layers of papyrus that lie one above the other (for an illustration of the layers as they appear to the eye see Figure 3). One needs to know one's limitations. Some find contact lenses useful for reading with the microscope; my insistence on spectacles has cost me much time, since these have to be put aside whenever I peer through the microscope.

Reading the papyri depends crucially on the types of images and technology that are available. Methods improved over time, at first slowly but more rapidly of late. Whether a papyrus needs reediting normally depends on the date of the prior edition, but most papyri edited before 1995 probably need to be redone. From their first unrolling, lenses and bright sunlight must have been used to read and draw them. Sunlight is still essential for reading the papyri in Naples, which are kept in a room with a glass ceiling; despite the heat that this generates, the overhead sunlight is essential. Transcriptions made on a sunny day will not be replicable when the sky is overcast, even with the best microscopes. What is seen in sunlight is so invisible in poor light that you will doubt that you ever saw it, and you risk erasing correct readings from your notes (experto crede). Because of the low angle of the sun, 


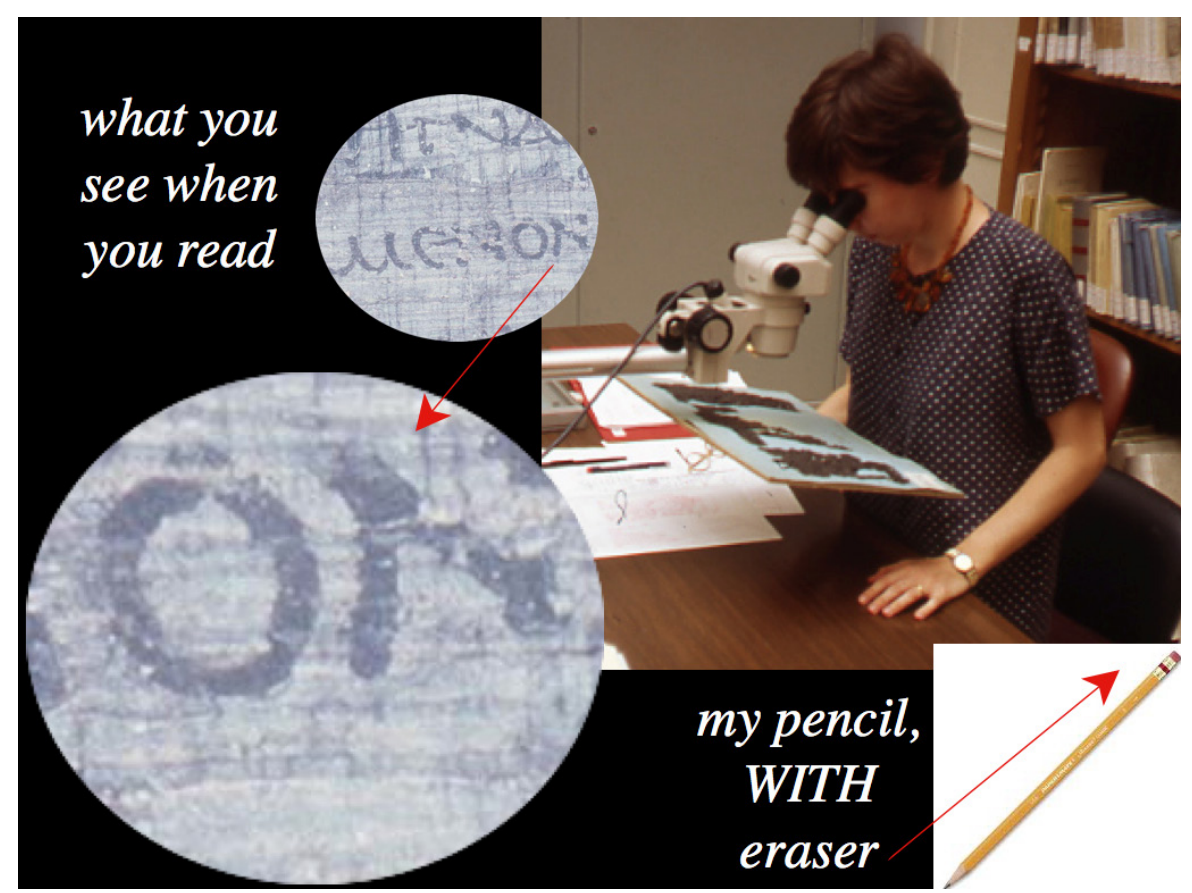

Figure 2. What you see through the microscope, P. Herc. $460 \mathrm{cr}$. I fr. I (photos with ring-flash R. Janko/B.N.N., copyright, all rights reserved)

the light in winter is inferior to that in other seasons; study in Naples is best undertaken between May and October. Eric Turner introduced binocular microscopes in about I98I. These earliest models relied on reflected sunlight as a light-source, but the shadow of the apparatus through which one looked drastically reduced the visibility of the papyrus. Better microscopes, with an annular light around the lens, were introduced in 1995; this counteracts the shadow from the apparatus, but of course the lenses still show only a small extent of the surface (Figure 2). In 20I3 even better models, with cold light-emitting diode (LED) light-sources, were brought in. Digital microscopes are usable only on those few pieces still mounted between glass. I will return at the end of this section to the difficulties, and the dire necessity, of working by autopsy from the original papyri, and will explain how best to do so.

The earliest method for reproducing papyri was of course drawing either in ink, as was practised by Piaggio himself, or (normally) in pencil, since no other method then existed. ${ }^{19}$ This resulted in four types of drawings (disegni), which almost always bear the number of the papyrus and the name of the draughtsman, a useful detail for establishing their date. 
(i) First is the Oxonian set on single sheets, now bound into nine volumes and kept in the Bodleian Library at Oxford; ${ }^{20}$ this set consists of almost all the pencil drawings that had been made down to January I 806 , including those made before John Hayter arrived in I802; the latter may be in ink, and drawings in ink usually predate $\mathrm{I} 800 .^{2 \mathrm{I}}$ Those made in Hayter's time bear in their lower left corners the original numbers that he assigned; as these are close to the binding, they are rarely visible in reproductions. ${ }^{22}$ Hayter's system of numbering is complete, distinctive, reliable and useful, because each cornice is assigned a capital letter of the alphabet (with $\mathrm{J}$ omitted), and then each column is numbered with a lower case letter; thus $\mathrm{H}: \mathrm{a}$ means the first column of the eighth cornice, and the drawing is labelled $\mathrm{H}$ even if the preceding cornici were never drawn. The same letters appear on the original cartoncini, where these survive.

(ii) The second set of disegni is the Neapolitan, which are made on the first recto of a bifolium: these were begun in 1807 in order to replace the Oxonian drawings after the latter had been removed from Naples, but were then expanded to include other, newly opened papyri. They ceased to be made after the unification of Italy in I 86I. These are kept in the Officina. They bear no cornice-number, but only a fragment number or column number (the term 'column' was used when the draughtsmen thought the columns formed a continuous sequence). Their numbering is not reliable, as they were subject to later changes which were often mistaken (see Part II).

(iii) A small group of disegni, made in I8 I9 under the supervision of Sir Humphry Davy and annotated by the Rev. Peter Elmsley, are bound and kept separately in the Bodleian Library; ${ }^{23}$ others from this same group, including some duplicates, are among the Neapolitan disegni. They bear, as usual, the papyrusnumber and the name of the draughtsman. A version of some of these (the 'King's Book'), painted in gouache by Sir William Gell and presented to the Prince Regent, is now in the Queen's Library in Windsor castle. ${ }^{24}$ However, I have eliminated it as an apograph. ${ }^{25}$

(iv) A few more drawings were made by Domenico Bassi and his draughtsman Mario Armani in the I9Ios; these are kept with the Neapolitan disegni, and add little to our knowledge. 
The early drawings are never wholly accurate transcriptions of the papyri, but also contain many traces, which have since disappeared; this is particularly true of the Oxonian set, which may show detached fragments in the margins and, where they exist, are generally better than the Neapolitan. Where outer parts of papyrus-rolls that were opened by scorzatura are involved (see Part II for what this means), the Neapolitan disegni are the primary witnesses to the text, since after the layer was drawn it was destroyed in order to reveal and to draw the layer beneath: such drawings usually bear the note 'non esiste l'Originale'. The early drawings should be read with the microscope, since this sometimes reveals traces of original readings that have since been falsely corrected.

The disegni in Oxford have suffered no modification since they were made. The Neapolitan disegni, however, were subject to some later annotation or supplementation, often anonymously. They were verified shortly after their creation by an interprete, who, unlike the draughtsmen, actually knew some Greek. He approved the accuracy of the drawings, marked them 'Visto buono', and signed his name; ${ }^{26}$ sometimes his supervisor did so too. The first use of the Neapolitan drawings was to serve as the basis for a transcript by an interprete. Many transcripts have been lost or were never made, but many more survive in the archive of the Officina, as I discovered. ${ }^{27}$ Hayter himself transcribed some of the Oxonian disegni; his transcripts are in Oxford. ${ }^{28}$ The transcripts are valuable for three reasons: they sometimes show lost letters (but one must exercise caution, since the interpreti supply lost letters without using brackets), they occasionally record lost fragments, and they are the first scholarly work on these pieces.

The next step was to engrave the Neapolitan drawing onto a copper plate; this action was authorized by the leading interprete, who signed the drawing with the command s'incida. Beginning in the 1830 , the engraver countersigned and dated the second recto of the bifolium that bears the drawing; he also put his name and that of the disegnatore onto the plate. Proofs ('prove di stampa') of these engravings were then made; these too are kept in the Officina. If the drawing is lost, which is occasionally the case, the prove become its primary source; in any case they must always be checked, because they may contain valuable information like original fragment-numbers (often under erasure themselves, with one number in ink and the other in pencil), which on the drawings themselves may have been deleted without trace or otherwise altered; these details matter for the reconstruction (see Part II). Lastly, the copper-plates were printed in the Herculanensia Volumina series 2, 
sometimes with bad 'corrections' initialled by Minervini and Fiorelli, who often introduced errors into the plates in $H V^{2}$. Even the plates must be collated, because the gradual deterioration of the papyri sometimes brought to light letters that were previously covered by the layer above, and could be added to the plates in later stages of engraving. However, as one would expect, the plates normally introduce error rather than improvement. ${ }^{29}$ Lastly, Theodor Gomperz' copy of the $H V$ in the library of the University of Vienna contains valuable marginal material, ${ }^{\circ}$ as does the archive of Christian Jensen and Wolfgang Schmid held in the Papyrussammlung at the University of Cologne..$^{31}$

Photographs of the papyri taken with ordinary wavelengths of light are almost always unsatisfactory. ${ }^{32}$ The first set of them was published in Milan in I9I4 as $H V^{3}$, containing papyri I050 and I457. Ordinary photographs have two defects: the contrast rarely suffices to reveal all the details, and the folding of the surface obscures many of the traces. However, colour photographs taken in ordinary light through a binocular microscope with a ring-flash around the lens, a technique developed by Knut Kleve, produce extraordinarily good images of an area perhaps averaging $4 \mathrm{~cm}$ high by $6 \mathrm{~cm}$ wide. These will show you perhaps seven lines with a width of eighteen letters in each; they still have shadows where the gradients of the papyrus are steep, but the ring-flash reduces the effects of folding. Since the area photographed is small, the technique is laborious, but the results are excellent (Figure 3 ). The image can of course be magnified by digital enhancement.

Infra-red photographs increase the contrast between the ink and the background, which can be further enhanced by digital processing; thus the original infra-red photographs of the Derveni papyrus, which were taken before it was mounted between glass sheets, are still one of the best ways to read its text. ${ }^{33}$ The 'multi-spectral' images (MSI) produced by the team of Steve Booras from Brigham Young University, mostly at wavelengths of about 940 nanometers, used excellent lighting from multiple directions. ${ }^{34}$ This too helps to 'flatten' the papyri. Even so the folding and the superposed layers still cause distortions and a high risk of false readings. Holes in the papyrus that are too small to allow the backing to become visible are indistinguishable from traces of ink (Figure 4). ${ }^{35}$ Unfortunately the MSIs were taken without a scale, which makes them rather hard to use for reconstructing the volumina (see Part II). Each image shows an area about two columns wide by sixteen lines high ( $\mathrm{I} 4 \mathrm{~cm}$ wide by $8 \mathrm{~cm}$ high). The individual images can be stitched digitally into larger images of whole cornici; the stitching very 


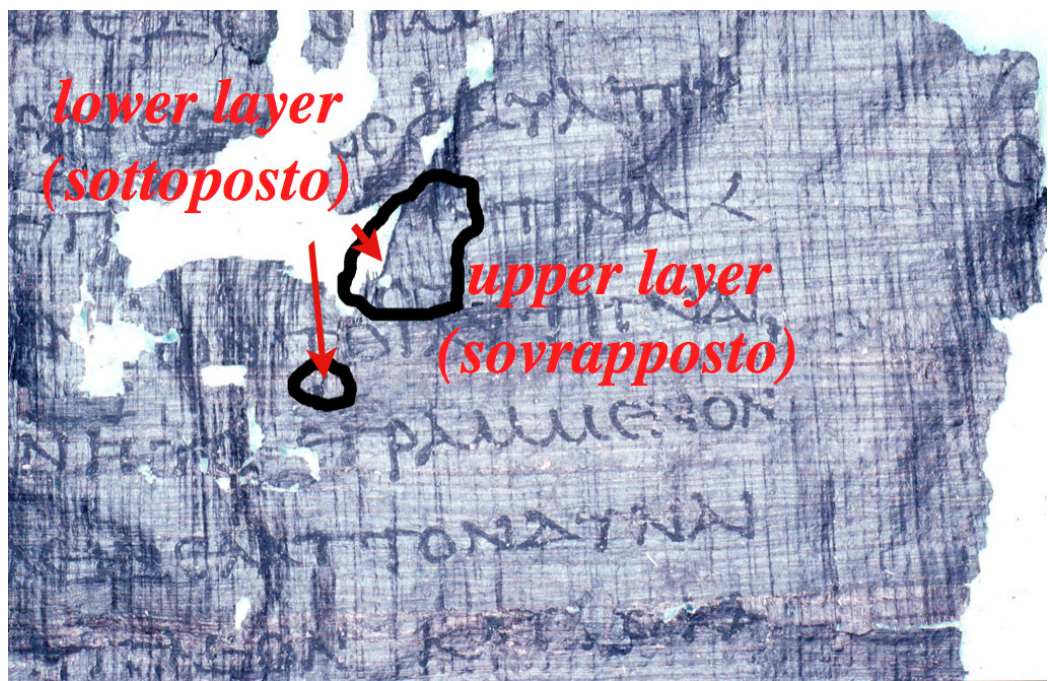

Figure 3. Detail of P. Herc. $460 \mathrm{cr}$. I fr. I of Philodemus' On Poems I, showing layers (photo with ring-flash R. Janko/B.N.N., copyright, all rights reserved)

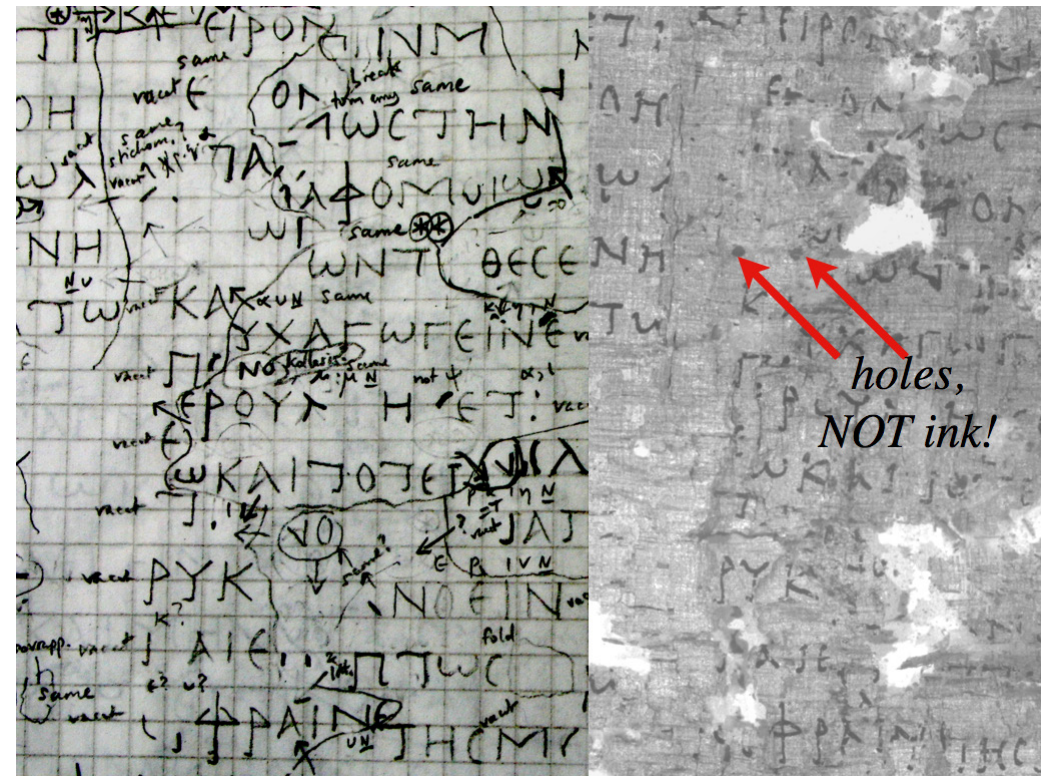

Figure 4. Detail of notebook showing notations of vacant space, layers, variants in disegni, date and time (photo R. Janko), with MSI image of P. Herc. $994 \mathrm{cr}$. I I showing holes that appear as ink (photo Brigham Young University/B.N.N., copyright, all rights reserved) 
rarely causes problems. They can be profitably studied on very large computer-monitors. Studying infra-red images alongside photographs taken in ordinary wavelengths of light with a ring-flash is a good approach, but studying them along with drawings corrected against the original papyrus is in my view the best method; the extra time it takes is rewarded with a higher degree of reliability in the results.

The most recent advance, pioneered by Kathryn Piquette from the University of Cologne (Piquette forthcoming), is Reflectance Transformation Imaging (RTI) at infra-red wavelengths. In this method, multiple images are taken from different angles and combined digitally. The viewer can alter the direction of the light to make it rake across the surface; a still photograph yields a very imperfect recreation of the extraordinary effect (Figure 5). This is the best approximation to looking through the microscope that I have experienced, since different layers are clearly visible in full perspective. However, it has the same drawback as microscopic study, viz. that only a small portion of the curved portions of the papyrus is fully visible at once. At the time of writing there are other difficulties: the making of such images is highly labour-intensive, and the file-sizes are enormous.

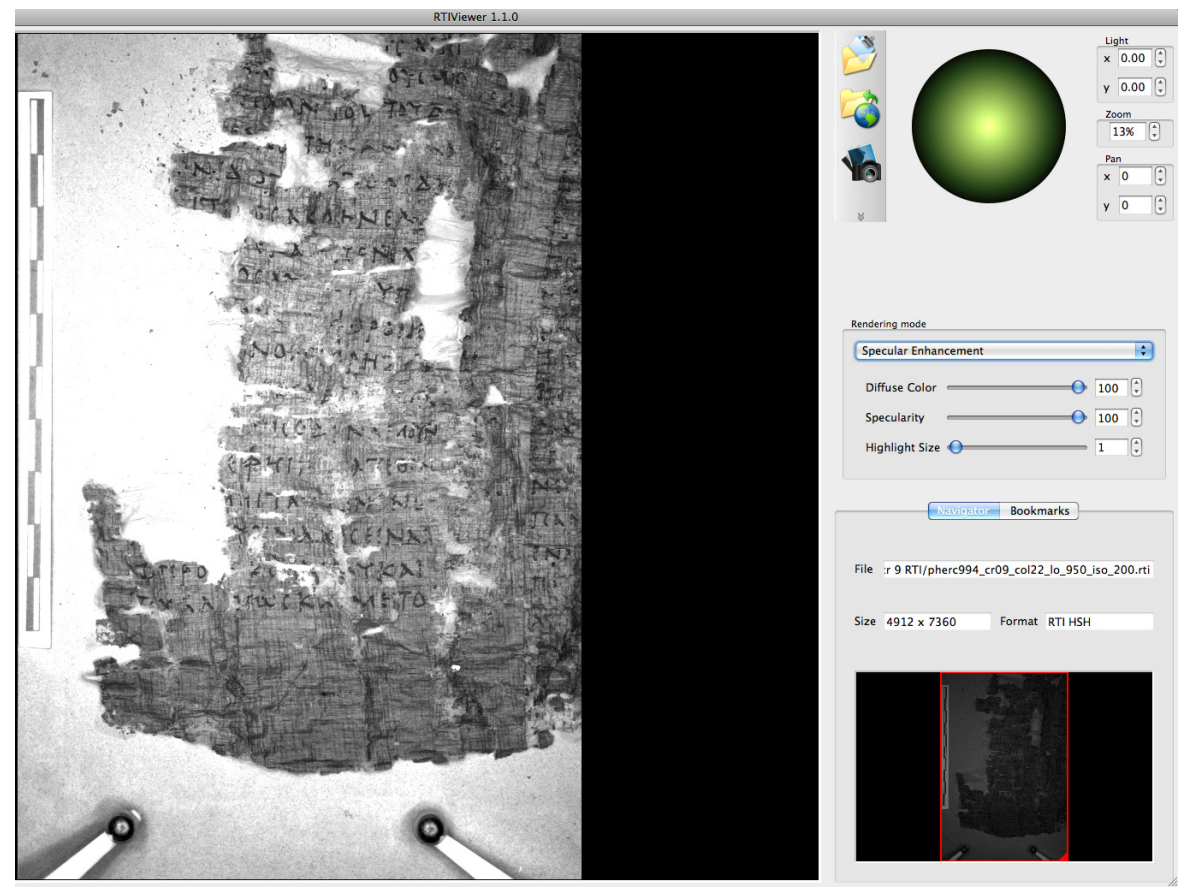

Figure 5. RTI image of P. Herc. 994 cr. 9 displayed with RTIViewer V.I.I (RTI image Kathryn Piquette/B.N.N., copyright, all rights reserved) 
To return, finally, to reading the papyri by autopsy through the microscope, this is an utterly enthralling task, but not a simple one. It is expensive to stay in Naples, and time in the Officina is at a high premium. One must plan visits carefully so as to avoid holidays. Generations of scholars have lamented that the gates of their paradise are open for so few hours - from 8.30 a.m. until I.30 p.m. on weekdays; a passport is required for entry, and the Officina now closes on Saturdays. It is worth asking in the Officina whether items from the archives can be transferred to the Sala dei Manoscritti downstairs, so that they can be read there after the Officina has closed. It is crucial to start early each day and to bring to the library without fail all the necessary items passport, pencils, pencil-sharpeners, rulers, pens, notebooks, and a large bottle of water. Forgetting even one minor item can cost much time, since it takes so long even to traverse the library from its entrance, where one must leave one's bag in the lockers, to the Officina, let alone to retrieve something from one's lodging.

Since at least a day is needed to verify even one column of papyrus, every effort must made to enhance what can be done there by preparation in advance. The papyrus cannot be read simply by leaving it to lie flat under the microscope, since this reveals almost nothing. Instead, the reader must support with one hand the cornice on which the papyrus is mounted, and take notes with the other. Only a few letters from a couple of lines are visible at a time, and at higher magnification only three or four letters, with just the edges of the line above or below (this applies too to imaging the Derveni papyrus with the USB microscope). Thus one is in constant danger of losing one's place. Doing so is worse than an annoyance, since regaining one's bearings takes precious time. There are two ways to reduce that risk.

First, one should bring to the Officina a set of print-outs of the cornici, not so much for the sake of the traces as for the pattern of holes in the papyrus; when one looks at the papyrus with the naked eye, as one must when trying to find one's place, holes of a particular shape are easier to locate than are individual letters. The print-outs can also be used for recording measurements (see below).

Secondly, for the difficult task of recording one's results, it is crucial to use only pencils with erasers at the opposite end, so that the implement can be reversed with one hand without either putting it down or taking one's eye off the microscope; one needs constantly to alternate between writing and erasing (mostly erasing). Employing such pencils reduces the risk of getting lost in the papyrus; the use of a separate eraser takes 
far too much time, as it increases that risk. Many pencils should be brought, all sharpened in advance, with erasers that are not worn down and graphite that rarely breaks.

The best method for recording results is NOT by making a drawing from scratch by autopsy. That approach carries a great danger of inaccuracy and is extremely time-consuming - a major disaster in the Officina, given its limited hours of opening. Instead, one must prepare in advance a drawing in pencil, and then correct and annotate it by autopsy, always in pencil (Figure 4). I have found it best to use MSI images as the basis of drawings on squared paper, bound together in the type of $\mathrm{A}_{4}$ exercise-books that Italian schoolchildren use; loose sheets get lost too easily. One must begin the drawing where there will be enough paper to finish it, perhaps at the upper left corner of an opening, and leave a blank line between each line of writing. It is also important, if having to turn a page, to indicate where the next column begins by drawing in the first letter of each line, so that the successive columns can be aligned and the intercolumnium is carefully checked. Readings derived only from the disegni or other sources should be written in lightly between the lines, so that one remembers to verify them. Where textual deletions are proposed, one should add a note to check whether there are expunctionpoints ('cancel dots') above the letters, as these are particularly easy to miss. Paragraphi should be marked for verification, since they are often confused with fibres. Vacant papyrus at line-ends should be marked 'vacat' so that one is not tempted later, when away from the papyrus, to suggest that a letter is lost there. The same is true for upper and lower margins and spaces left by the scribe as punctuation, which can provide crucial help for reconstructing a given passage, as can diacritical signs. Changes of layer are marked with arrows, indicating up or down; surprising readings should be marked 'sic' to show that they have been verified; traces to be checked can be marked as such, and the notation erased after verification. Crowding of letters towards the right margin must be noted, as it may betray the presence of that margin when it is lost. The time, date, and light should all be recorded. The time is important, because one needs to know how long it takes to verify the column; this helps with planning future visits to the Officina. The date matters because it can be correlated with the print-outs that I will discuss below. The light is important because, as we have seen, verifications carried out in bad light can be disastrous, leading to the abandonment of the true reading. One must always recheck work that is done in such conditions, and never erase or discard results that were obtained in good light. 
The drawings will need to be revisited several times until one is fully satisfied with the text that they yield. I have learned from painful experience never to alter them when I am not in the presence of the original. Others make notes on large printouts of the MSI images; this may seem less laborious at first, but has the serious disadvantage that such annotations need for legibility to be in ink, but will inevitably need correction, which is certain to become both messy and dangerously confusing. Annotating printouts of the text while looking at the digital image on one's computer-screen and only checking the original from time to time seems to work for some scholars, but I worry about the accuracy of their results. In my experience reflections from the glass ceiling make the screen hard to see. In addition, a slow and microscopic perusal of the entire surface yields many unexpected and valuable surprises, such as annotations in apparently blank upper or lower margins, stichometric signs or points in the left margin, punctuation, faint supralinear corrections, faint deletion-lines through letters, expunction-points, abortive or unfinished letters at line-ends where the scribe was slow to realize that he needed to start a new line, and alignment dots at the top of the left margin for column-layout. ${ }^{36}$ One must constantly watch for all these phenomena.

Print-outs of the stitched digital images are essential not only for finding one's place, but also for recording measurements (Figure 6). These can be written directly onto the printout, preferably in a red or blue pen with a very fine point. No drawing of one's own will be accurate enough for recording such measurements, whereas on printouts one can mark the beginning and end of every measurement that is noted. Yardsticks and digital calipers are kept in the Officina for this purpose; the digital calipers are better, since yardsticks cause serious parallax errors. Every possible measurement should be recorded, from the height of the letters, height of the interlinear spacing, width of the lines, and width of the intercolumnium to the height of whole columns and of the upper and lower margins: one never knows what will be needed later. Others prefer to annotate the digital images on their computers. At least this is less fraught with risk than is relying on them for reading the ink.

Above all, the exact height and width of the entire cornice must be established and checked, since this is needed for scaling the digital images, which do not have a scale in the picture. For the purposes of reconstruction, an equally important measurement is the distance from the left margin of one column to the left margin of the next. The column- 


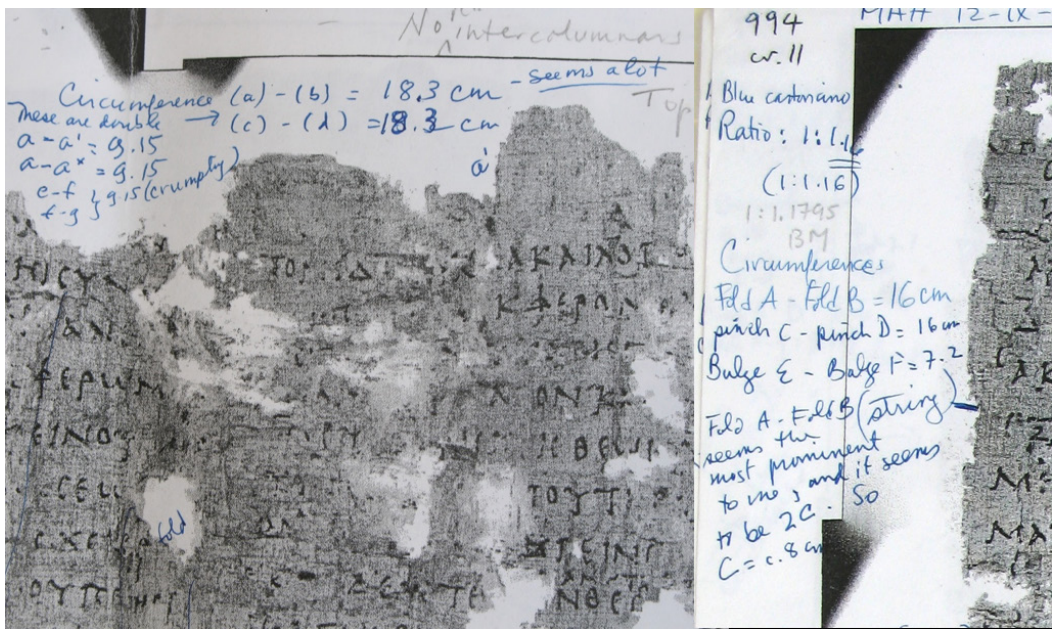

Figure 6. Measurements recorded on print-outs of MSI images of P. Herc. 994 crr. Io and I I (photos R. Janko/B.N.N., copyright, all rights reserved)

to-column width is normally fixed in prose texts. ${ }^{37}$ Since this number will be multiplied by a large factor when the entire roll is reconstructed, it is vital to establish the average with the greatest possible exactitude. In prose texts written in short lines ( $\mathrm{I}_{3}-23$ letters), as is usual in the Greek texts from Herculaneum, this dimension should vary hardly at all, but be almost exactly fixed, as if the scribe used a mark on his pen-box each time he wished to place the left margin of the following column. However, it must always be verified, since any variations will affect the reconstruction profoundly (see Part II).

Equally important, the distances between successive sezioni and circumferences must be determined. ${ }^{3}$ One must distinguish between sezioni, i.e. repeated distances of half a circumference or less into which papyrus roll tends to fracture, and full circumferences, in which there are at least two sezioni. Indeed, if the cross-section of the papyrus was not round or elliptical, but pentagonal or hexagonal, as could happen if it was part of a stack of rolls stored horizontally, there may be five or six narrow sezioni in a single circumference. The circumferences were burned into the papyrus when it was carbonized. They can be found only by study of the original; in future one might be able to use Reflectance Transformation Images with a scale in them, if these can ever be stitched together. To find circumferences, one needs to search for recurrent patterns of damage and/or of elevation and depression, and measure the horizontal distances between them as exactly as possible, marking on 
the print-out the points where the distance begins and where it ends. Circumferences can be very difficult to isolate. Multiple measurements at the top, middle and bottom of the columns will be needed to verify that they have been found. Successive dimensions should always diminish fairly steadily towards the end of the roll. Such measurements need to be tabulated and collated to ensure that they do so decline. They are particularly difficult to make across a break between cornici. Although the Officina will permit two cornici to be studied at once, this hardly helps the calculation; the final result has to be determined by careful addition and subtraction, since the lateral margins of the cornici prohibit taking the measurement in a single operation. The outermost, widest circumference will be almost impossible to determine (unless the initial title of the roll survives), because the exterior of the roll is usually in worst condition. The innermost, on the other hand, is likely to be knowable. Many papyri were wound upon themselves and therefore have very small final circumferences, while others had a central rod (ỏ $\mu \varphi \alpha \lambda$ ó umbilicus) around which the innermost circumference was rolled. ${ }^{39}$

Lastly, papyrus-rolls were composed of separate sheets or kollemata, which were glued together with an overlap. $4^{\circ}$ The line where the two sheets join is called the kollesis (Figure 7). The finding of kolleseis is very difficult in carbonized papyri, since the eye tends to focus either only on the letters, or only on the fibres, and the latter are hard to follow under the microscope. The search for kolleseis requires a completely different kind of looking from that which is involved in searching for traces of ink. Sometimes a kollesis can be seen with the naked eye, because the upper layer overlies the lower, or the scribe tries to avoid writing over it. But often the digital images suggest a kollesis where none exists: the phenomenon is simply a crack. A separate horizontal scanning of the entire cornice, in which one's eye follows the horizontal fibres, is needed, with particular attention to places where the surfaces are unbroken. Reading the ink is so fascinating, and finding the kolleseis so tedious, that it is wise to note on the drawing that the latter task too needs to be done.

Kolleseis can usually be found by exercising great persistence, except in pieces were multiple layers are present. There are two clues. (i) Diagonal fibres are often present near a kollesis, where they were glued down by the glutinator as he put the roll together. (ii) There should be a vertical crack or break in the papyrus some $\mathrm{I}-\mathrm{I} .5 \mathrm{~cm}$ before the kollesis, which one often mistakes for the kollesis itself (Figure 7). The fibres will in fact be found to run on. This vertical break in fact corresponds to the 


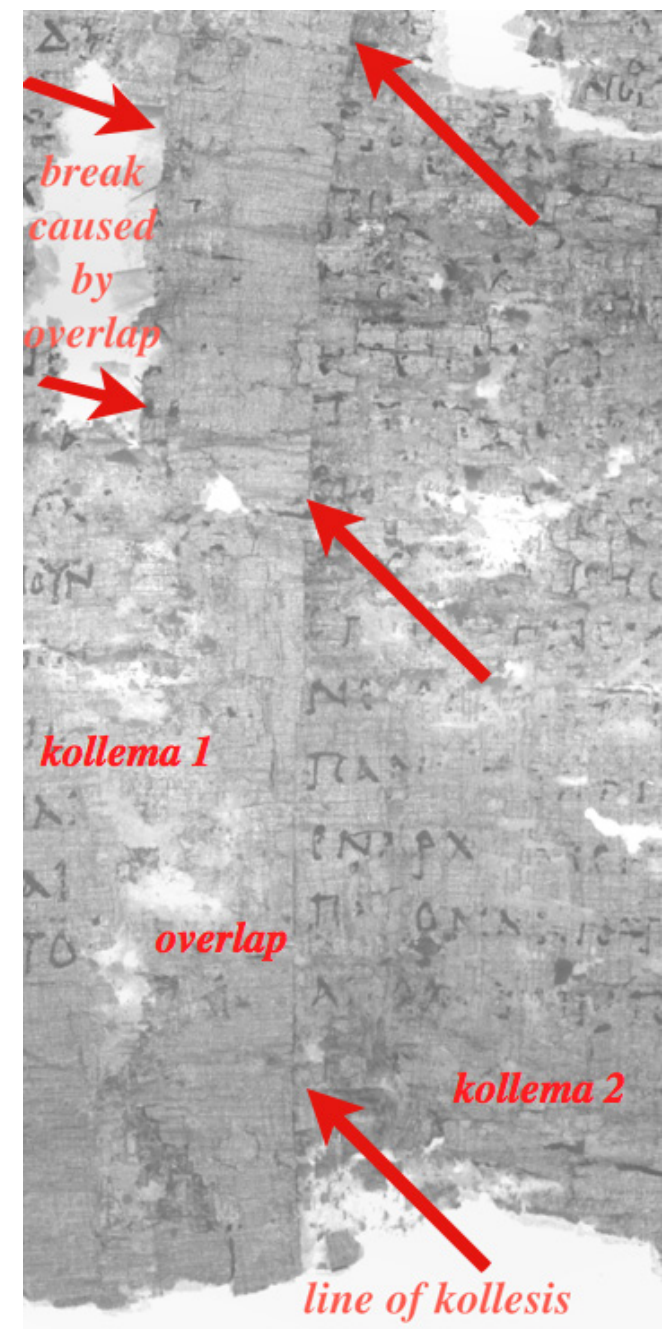

Figure 7. Join between kollemata at left margin of P. Herc. 994 cr. 9 fr. 23, with crack preceding the kollesis (MSI image Brigham Young University/B.N.N., copyright, all rights reserved)

beginning of the underlying (rightward) sheet, which only becomes visible where the overlying (leftward) sheet runs out. But this latter transition is the only one that is directly visible, and this is where the kollesis is said to occur and whence the next kollema is measured. Once a kollesis is found, it should be verified at multiple heights in the column, and the location marked on the drawing and on the print-out of the digital image. Its distance from the left and right edges of the cornice, and from the next or previous kollesis, if known, should be measured in several 
places with the digital calipers. The measurements will vary slightly, since the sheets of papyrus from which the roll is made were cut manually, but the average width of the kollema can readily be determined. Knowing the average also helps one to discover further kolleseis, since one can work out roughly where they should fall and search for them there. The distances need to be measured precisely, since the kollemata can play an important role in reconstructing the volumina (see Part II).

After the papyrus has been drawn and the drawing has been verified, there begins the multi-stage process of establishing the text, which loops back into drawing the papyrus and forward into the process of reconstructing the roll. Often I am able to establish the readings accurately long before I can understand the text. I create a double-sided print-out of the preliminary text bound with a cover to protect it, since it will suffer a lot of wear. The text must be in columnar format, with a date and title (Figure 8). Each line is annotated at the right with a count of letter-widths, because I find that if I do not count the letters I fall into error in proposing supplements at the ends of lines. Also, if the scribe does justify the right margin and uses filler-signs based on the asteriscus $(※$ or $:<$, one must be careful to supply these where the line is broken

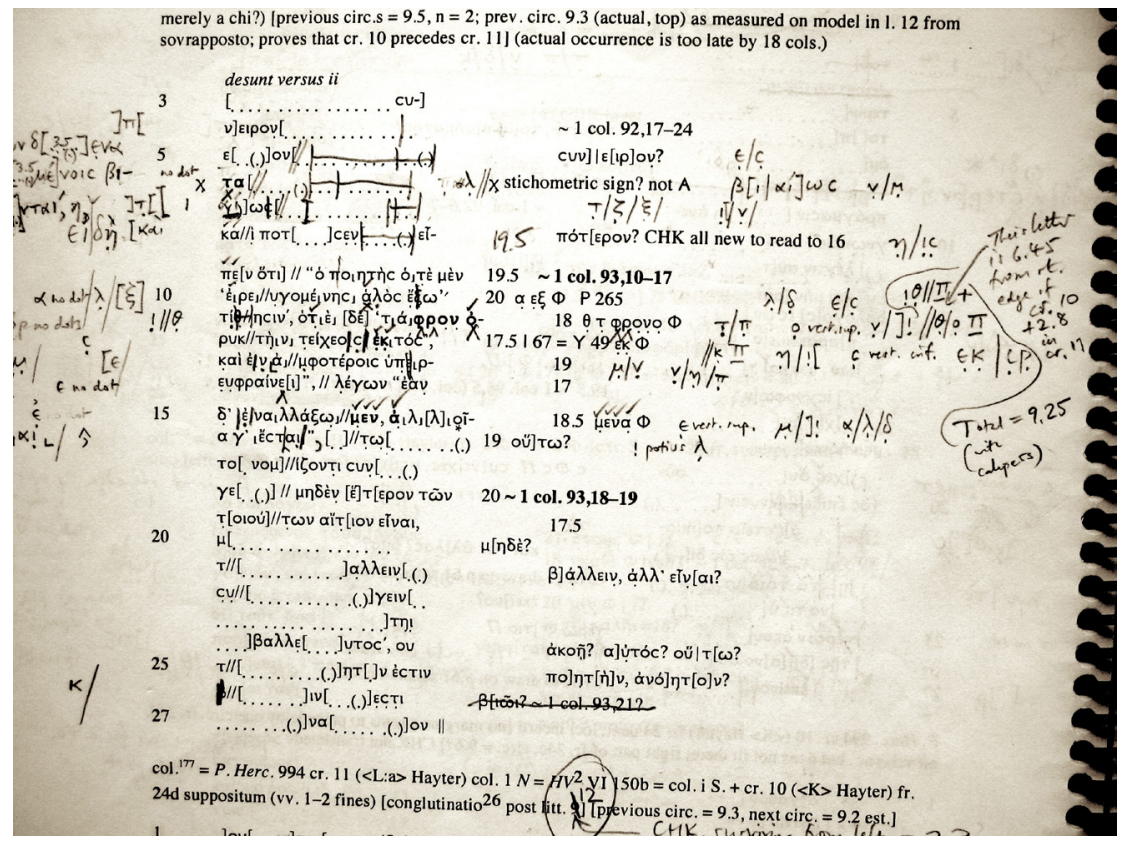

Figure 8. Detail of printout of Philodemus' On Poems 2 col. I78 (= P. Herc. 994 cr. Io fr. $24 \mathrm{C}+\mathrm{cr}$. I I col. I fr. suppositum) with counts of letter-widths and verifications (photo R. Janko) 
at the right and a letter or two short; they are often a valuable clue that one's initial supplement is wrong. One must also apply correctly the Greek rules of word-division. ${ }^{4 \mathrm{I}}$ Letters which need to be rechecked are temporarily printed in bold type, ${ }^{42}$ and the other possibilities are recorded in the right margin, together with suggested supplements. These must be verified from autopsy, because quite often traces emerge which confirm or disprove them. The apparatus records previous scholarly conjectures (if any) and possible readings of uncertain letters; this is kept current on my laptop computer, but is not taken to the Officina (nor do I carry my computer there, since there is neither need for it nor time to use it). When I return to the Officina, I annotate the bound text as well as the drawing. I mark each verification as it is made, noting the alternative readings of each trace in the right margin, and updating the drawing too as necessary; the double system reduces inaccuracy. I record in the print-out the date, the time and the quality of the light. I note in the right margin suggestions for supplements. All these notes are in pencil. After the Officina closes I work the changes into the text on my computer, and update the apparatus at the same time, recording the possible alternative readings of the damaged letters; this normally takes almost as long as the five hours spent in the Officina itself.

When further ideas occur to one, whether by free thought, from books ${ }^{43}$ or from digital searches of the Thesaurus Linguae Graecae (TLG), LSJ, or other sources, ${ }^{44}$ they must be marked as needing verification the next morning, along with any uncertainties in one's notes from the morning's work. Only once such queries have been clarified can forward progress through the text resume. The print-out, being bound, can be read and pondered even in places that are inhospitable to study, like trains and aeroplanes; but changes made when one is away from Naples must be marked in ink and verified later. Every rereading in Naples of the same parts of the papyrus requires a clean, new print-out, on which this process of verification is repeated until the text seems satisfactory. One's original notebooks will need to be checked many times before the text is finished, to see whether one did once confirm a given letter in Naples; it is unwise to go against what was recorded there, even if the digital image seems to show something else, although about half the time it does not mislead.

\section{Reconstructing the Papyrus}

Camillo Paderni tells us that 800 , or perhaps 8 I 5 , book-rolls of papyrus were found in the Villa dei Papiri at Herculaneum. ${ }^{45}$ However, many 


\begin{tabular}{|c|c|}
\hline $\begin{array}{l}N \text { 1081b set } \mathrm{D}(2 \text { layers, } 2 \pi \mathrm{r}=20.9) \text { [peeled off } \\
\text { before } 1763 \text {, scorzatura } 1823]^{\pi}\end{array}$ & -4 \\
\hline $\begin{array}{l}\text { P. Herc. } 994 \text { cr. } 1 \text { fr. A (3 layers, } 2 \pi r=? ?)[=N \\
\text { 1081b ultimo foglio, peeled off before } 1763]\end{array}$ & $\begin{array}{l}\text { P. Herc. } 994 \text { cr. } 1 \text { fr. B (3 layers, } 2 \pi r=20.3)[=N \\
\text { 1074b ultimo foglio, peeled off before } 1763]\end{array}$ \\
\hline $\begin{array}{l}N \text {. } 1081 \text { b scorze, sets A + B }(9 \text { layers, } 2 \pi r=19.2 \\
\quad \rightarrow 17.6)[1823]+P . \text { Herc. } 1677 \text { a frr. } 3-4 \\
{[1763-5]^{\sharp}}\end{array}$ & $\begin{array}{l}N \text { 1074b scorze }(7 \text { layers, } 19.0 \rightarrow 17.9)[1823]+P . \\
\quad \text { Herc. } 1677 \text { a fr. } 4[1763-5]\end{array}$ \\
\hline $\begin{array}{l}\text { P. Herc. } 1676 \text { cr. } 1 \text { ( } 2 \text { layers, } 17.6 \rightarrow 17.1)+N \\
1081 \text { b set } C \text { fr. } 12(17.3) \text { बा } \\
\text { P. Herc. } 1676 \text { cr. } 2(3 \text { layers, } 17.1 \rightarrow 16.9) \text { था } \\
\text { P. Herc. } 1676 \text { crr. } 3-5 \text { (7 layers, } 16.9 \rightarrow 16.2) \\
\quad[1763-5]^{\text {म }}\end{array}$ & 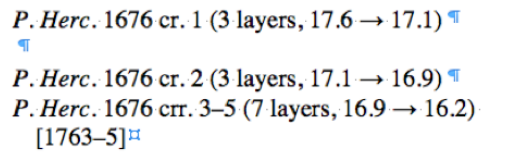 \\
\hline $\begin{array}{l}\text { P. Herc. } 1419 \mathrm{c} \text { cr. } 2 \text { (3 layers, } 2 \pi r=15.7 \rightarrow \\
\text { 15.4) }[1763-5]^{\text {म }}\end{array}$ & $\begin{array}{l}\text { P. Herc. } 1419 \mathrm{c} \text { cr. } 2 \text { (3 layers, } 2 \pi r=15.7 \rightarrow 15.4) \\
{[1763-5]}\end{array}$ \\
\hline $\begin{array}{l}\text { P. Herc. 1677a crr. 3-4 (7 layers, } 15.4 \rightarrow 14.5) \\
{[1763-5]^{\text {g }}}\end{array}$ & $\begin{array}{l}\text { P. Herc. 1677a crr. 3-4 (7 layers, } 15.4 \rightarrow 14.5) \\
{[1763-5]^{\text {H }}}\end{array}$ \\
\hline $\begin{array}{l}\text { P. Herc. } 994 \text { crr. } 3-19+2 \text { (104 layers, } 14.5 \rightarrow \\
\text { 1.3) }[1802-3]\end{array}$ & $\begin{array}{l}\text { P. Herc. } 994 \text { crr. } 3-19+2(104 \text { layers, } 14.5 \rightarrow 1.3) \\
{\left[\begin{array}{l}{[1802-3]} \\
\text { f }\end{array}\right.}\end{array}$ \\
\hline
\end{tabular}

Figure 9. Table of the 'papyri' of Philodemus' On Poems 2, showing stages of unrolling and decline in circumferences (table R. Janko)

were broken up before or during their opening, with the result that about I,830 items are currently inventoried as a P. Herc. In theory this yields an average of 2.3 items per roll; in practice this is not a helpful guide, as the standard deviation is large. A great number of items correspond to only one roll. However, many rolls were divided into many items: thus Philodemus' On Poems 2 consists of six different and very dissimilar P. Herc. numbers (Figure 9). On the other hand, some items contain pieces from more than one roll: P. Herc. I4I9 comprises parts of at least six. No catalogue was made for the first thirty years after the discovery, as there seemed no reason to do so, when nothing had been opened or read. Later the difficulty of tracking so many equally illegible objects introduced considerable confusion into the collection. ${ }^{46}$

The old catalogues are an essential guide to how a given papyrus was unrolled. ${ }^{47}$ The process may well have been more complicated than at first appears, or is suggested in the Catalogo dei Papiri Ercolanesi of I979; understanding it can be decisive for the reconstruction, since it is vital to know the sequence in which pieces of a roll were opened and/or read. The earliest work on them is the least well recorded..$^{8}$ Piaggio compiled the earliest catalogue in March to June of I782;49 its surviving portion lists and describes papyri numbered 3 2 2-I 695 , which was the highest number then used. ${ }^{50}$ Historical work to establish exactly which papyri he unrolled in which order and between what 
dates has progressed significantly in recent years. ${ }^{5 \mathrm{I}}$ One can easily trace work on a given papyrus down to $c$. I $8 \mathrm{I} O$ via the contemporary lists of papyri, which have all been published. ${ }^{22}$ However, three subsequent inventories have not: (i) that of 18 I $9-23,53$ (ii) Castrucci's inventory of I $824,{ }^{54}$ and that of 1853.55 These are essential sources for the massive opening of scorze that began in c. I 820 . Unfortunately they are full of erasures and additions by unidentified hands of unknown date, and can be inaccurate. However, by combining these with other sources one can often correct serious errors.

The records of the storage of the papyri reveal the sequence and approximate dates when they were unrolled, since the call-number of any particular papyrus, which is recorded in the inventories, can be correlated with the date of construction of the cabinet in which it was stored..$^{56}$ Lastly, the signatures of the draughtsmen, engravers, interpreti and superintendents on the Neapolitan disegni and engravings are a useful source for chronology, since the dates of employment of the personnel of the Officina are in principle knowable from the archives, ${ }^{57}$ and a particular pairing of employees may provide chronological precision.

The task of reconstruction is hard to undertake in Naples, where few of us have the basic necessities for it. These are an oblong table large enough to support a two-metre length of a paper model of the roll at actual size, excellent light, tranquillity, and plenty of time. But the basis for this task must be laid in the Officina, above all by reading the papyrus accurately, measuring the sezioni and circumferences, recording the annotations on the cornici and disegni, and investigating all the old catalogues and relevant archives.

The first desideratum is to link the text to a particular scribal hand and to gather together all the pieces on the same topic that are written in that script. There is no complete inventory of the hands in the collection. A start on classifying them was made by Cavallo in I983. His work revealed the useful heuristic principle that the scribes who copied Epicurean authors are often represented in the collection more than once, even for different works by the same author, but that the other texts, e.g. those of Chrysippus, are in hands that do not recur, as if these items were copied elsewhere and added to the collection at different times..$^{8}$ Thus the reconstruction of Philodemus' On Poems 2 was simplified by the fact that all the items in Cavallo's hand 'Anonimo VIII' are about poetry and in fact belong to one and the same roll. Subsequent identifications of hands have been made piecemeal and are mostly published in Cronache 
Ercolanesi, the main journal for this field of study. Further information can be found via the multimedia catalogue of the Herculaneum papyri, Chartes; ${ }^{59}$ this contains low-quality images of (in principle) all the different hands in the collection.

The approximate location of pieces of papyrus within a given roll can be found in several ways. Which methods apply depend on whether the fragment is from a scorza or a midollo (see Figure Io). These terms derive from the earliest days of Herculanean papyrology. They denote (a) a stack of pieces from the outer layers of the roll (scorza, 'bark' as of a tree, plural scorze) and (b) its cylindrical interior, still rolled up (midollo, 'marrow' as in a bone). This distinction also applied to the Derveni papyrus, where frame ( $\pi \lambda \alpha$ oío) I, called A by its editors, contains the midollo. ${ }^{60}$ I will begin with (a), the reconstruction of the outer parts, which is known as the Delattre-Obbink method.

\section{(a) The Delattre-Obbink method for reconstructing detached fragments}

When carbonized scrolls are first opened, at least two stacks of scorze are peeled off from the outsides of the roll, one from each side of it, to yield two hemicylinders; if, in order to open the roll, it had to be cut in half, there would be at least four stacks of scorze, and any particular stack might separate into more than one distinct 'stack' (Figure Io). These stacks retain the original curvature of the roll from which they derive; the interior surface displays a layer of writing, and the exterior surface should represent the exterior either of the stack or of the roll itself. Since, at Herculaneum, the layers in the scorze were often stuck together, for a long time they were left untouched.

Once all the usable midolli and other material that could be opened without destroying it had been exhausted, in about 1820 , the unrollers turned to the stacks of scorze. These they 'opened' as follows: they made a disegno of the uppermost (innermost) layer of writing that was exposed, numbering it ' $I$ '; they then scraped away that layer, destroying it in the process and thereby exposing another layer of writing; they then copied the next layer, numbering it ' 2 ', and continued to repeat this process until the lowest (outermost) layer in the stack was attained. This lowest layer, which they called the ultimo foglio, i.e. the 'last leaf', ought in principle to survive, but was sometimes destroyed in a vain effort to separate further layers. The whole process is called scorzatura; its result is a series of drawings, often many drawings (up to thirty or 
a

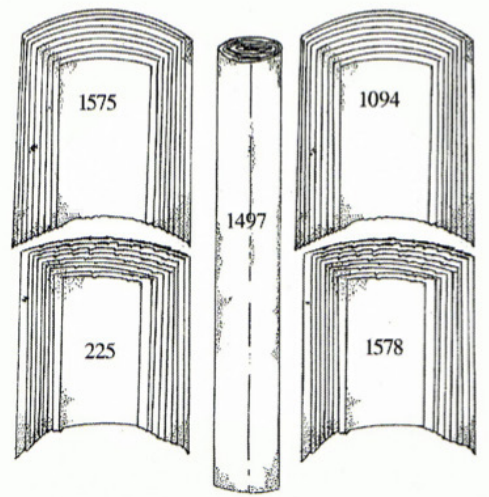

$b$

1094
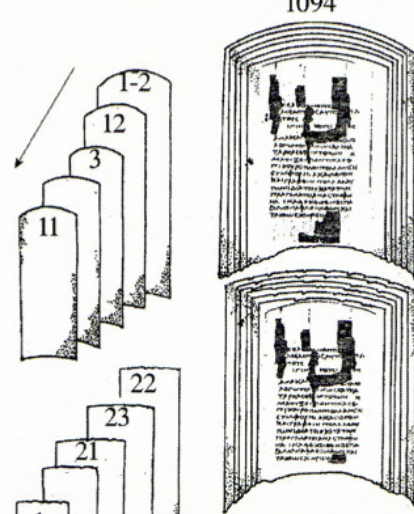

1578
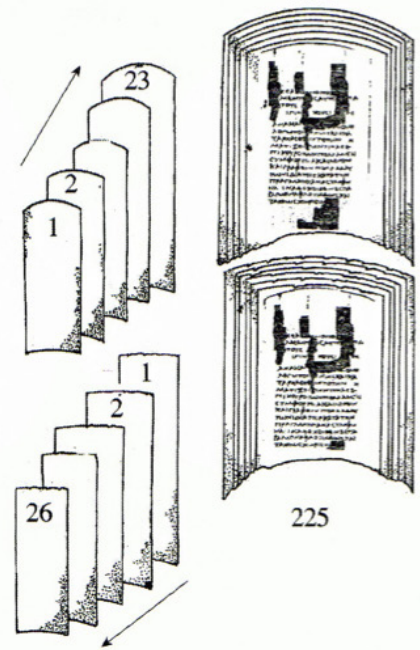

225

Figure 10. Diagram to illustrate the Delattre-Obbink method (reproduced by permission from Delattre 2006, Planche 5)

so), the last of which ought to depict the surviving ultimo foglio. Joins within each set of scorze are impossible, unless between small pieces of overlying and underlying layers (sottoposti and sovrapposti). ${ }^{6 \mathrm{I}} \mathrm{By}$ thinking in three dimensions, one can use this method to reconstruct a cross-section of the roll (Figure II).

For at least a century, the way in which the scorze were opened was forgotten. Nobody understood that the first disegno, i.e. the item numbered ' $I$ ', would be the last in the series, because the interior of the roll would contain the end of the text, whereas the drawing of the ultimo foglio, which would have the highest number, would actually be the 


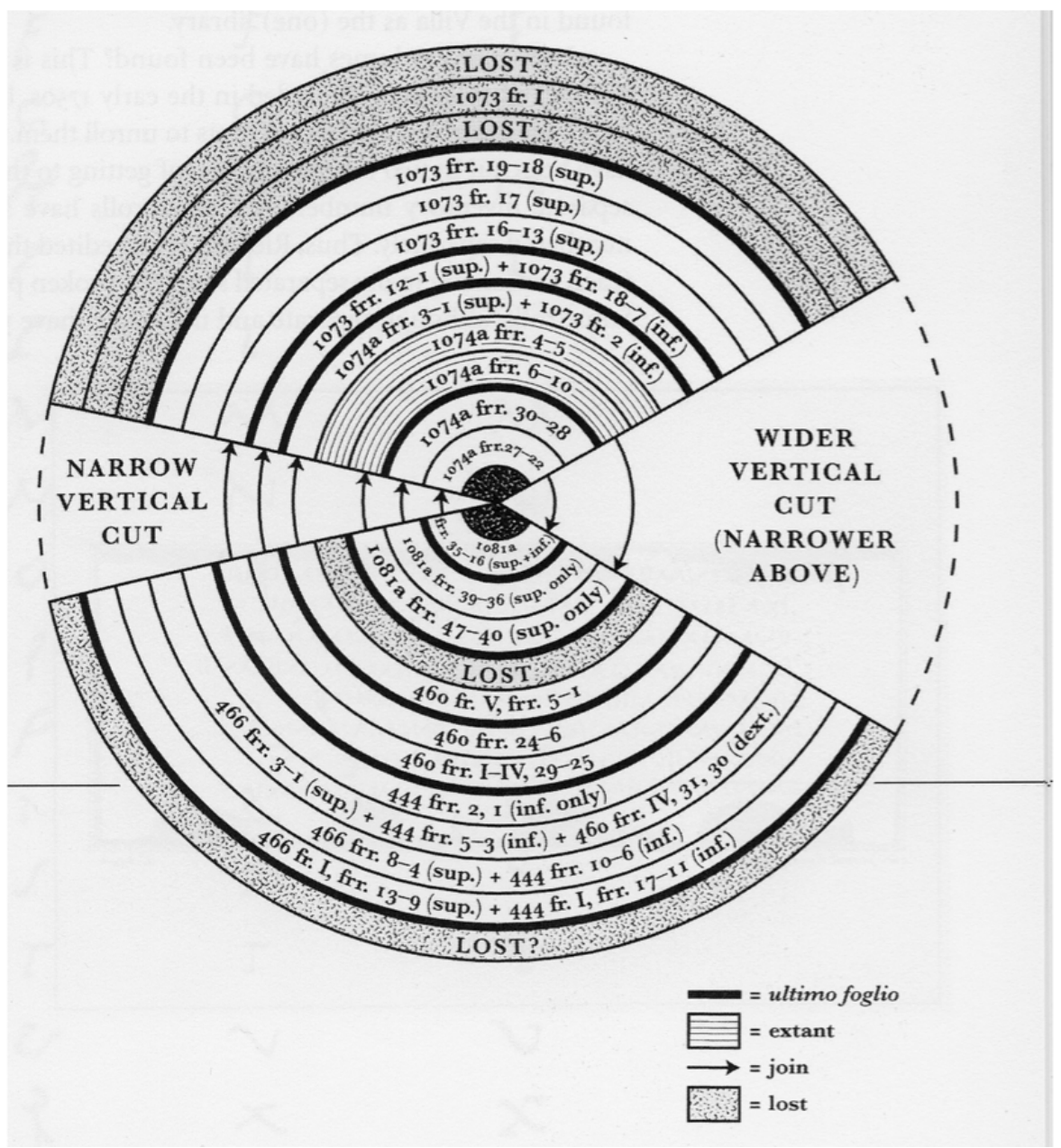

Figure 11. Cross-section of the roll of Philodemus' On Poems I (diagram R. Janko)

first in the series and form the outermost layer, bearing on it the start of the text (Figure Io). To restore the original sequence of fragments, the separate sets of scorze need to be reintegrated in alternating backwards order. Schober had some inkling of this is his unpublished edition of Philodemus' De pietate, ${ }^{62}$ but Delattre, in preparing his edition of De Musica IV, was the first to comprehend and publicly explain this principle. ${ }^{63}$ Obbink intuited it independently in editing De pietate. ${ }^{64}$

One obstacle to the Delattre-Obbink method is that the draughtsmen (disegnatori) did not follow scientific principles. They did annotate the drawings to indicate that 'the original does not exist' (non esiste l'originale), but often they did not draw all the pieces or layers. They 
might omit a layer that contained a few letters from the end of one column, the usual intercolumnar space, and the first few letters of the next column, or they might omit just one of the two columns, normally whichever contained fewer letters. Layers showing the edges of columns are invaluable for discovering the correct sequence, since they can be joined to a piece that contains the remaining width of the column, but they are often missing. Again, if parts of two columns appeared in the same layer, the draughtsmen sometimes drew them separately and gave them separate numbers, but sometimes drew them as a single disegno. If the edge broke off a larger stack, the resultant small stack might be given a separate sequence of drawing-numbers within the same set. Thus in those drawings in $\mathrm{N}_{\text {IO8 }} \mathrm{I}$ that are from On Poems 2 a stack of three fragments forms the right-hand upper edge of the main stack. Often the shapes of different stacks from the same roll will be uniform, so that they can be sorted out.

Problems in the sequence can be surmounted by close attention to the shape of successive fragments. Is each a left or a right edge? Does it have an upper or lower margin? How many letters does it preserve? On this basis, one should aim to reconstruct the shape of the original stack of scorze, and the surviving ultimo foglio can be used to determine its original exterior dimensions. These should be compared, where possible, with the dimensions in Piaggio's catalogue.

A second complication is that the draughtsmen sometimes depicted two or more layers in a single drawing. If the same layer appears in two successive drawings, the same letters will appear in them as sovrapposti or sottoposti (i.e. layered above or below); this can be a valuable clue to the correct sequence. In N Io8 I of Philodemus' On Poems 2 the unroller missed the fact that the scorza was cracked across horizontally, and rarely exposed the upper and lower parts of the same layer at the same time. When the left margins of the upper and lower layers coincided, he drew the upper and lower parts of different layers as if they were the same layer. The problem was insoluble until I treated the upper and lower parts of each disegno as two separate sub-series, with a system of numeration to reflect this situation. Once such a situation is understood, the separate fragments then count as sovrapposti and sottoposti relative to each other, a fact which is vital to the reconstruction.

A third obstacle to the method is that the pencilled numbers on the disegni were sometimes changed after the operation of scorzatura, normally by erasure and writing a new number over the old one; sometimes the numbers were altered more than once. Such renumbering 
can ruin the prospects of reconstruction. The drawings themselves must always be inspected under the microscope; one can usually see that an erasure has been made, but it is often hard to determine the original reading. Sometimes two sets of unrelated drawings have been combined; one common technique for combining them was to prefix a ' $I$ ' to the original number, so that ' 2 ' becomes ' $\mathrm{I} 2$ ' and so on. Minute inspection of the palaeography of the draughtsman can sometimes reveal renumbering. The solution to this problem may lie in the archives of the Officina. The drawings were meant to be engraved as copperplates, but this often happened only years later. Proof copies of the engravings (prove di stampa) were produced, which the Officina has preserved; these normally bear the number which they then had. This too may well be changed, but since the annotations are usually in ink, and the corrections are often in pencil, they are easy to decipher (Figure I2). Also, after $c$. 1836 the Registro de' rami incisi ${ }^{65}$ records not only the engraver's identity but also specific fragment-numbers; by elimination and comparison with the Herculanensia Volumina, which identify the engraver, one can often determine which fragment is meant. In addition, the transcriptions of the interpreti may also disclose earlier numberingsystems. Tabulation of all the data will make any patterns in them easier to discern. On very rare occasions, renumbering conceals the blending

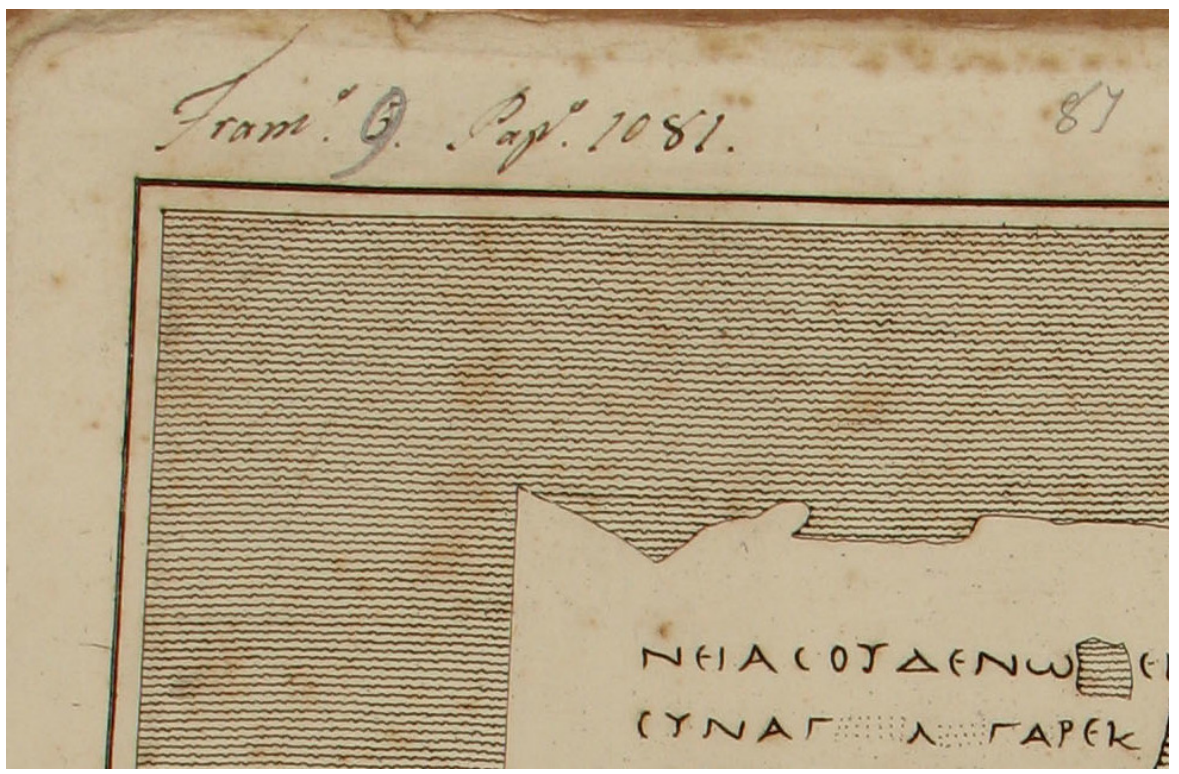

Figure 12. Detail of prova di stampa of P. Herc. Io8 I fr. 9, to show changed numeration (photo R. Janko/B.N.N., copyright, all rights reserved) 
of different hands within the same 'papyrus', where drawings of two rolls in two different scripts have been mixed up. Thus there are two

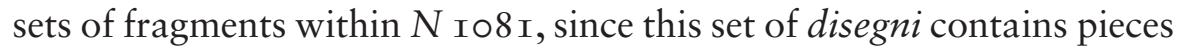
from two rolls in two different hands.

I discovered a fourth complication when I noticed that some of the sequences of fragments in Delattre's reconstruction of On Music 4 ran forwards rather than backwards, and that these same fragments were the only ones that actually survived. I deduced that Piaggio made some experiments at lifting layers one by one from the outside or exterior of the roll, a process which I called sollevamento 'lifting off'; ${ }^{66}$ in theory this should yield a series of extant pieces from one side of a roll in the correct sequence, separated by equivalent pieces from the opposite side of each circumference. In practice, however, more than one layer would often separate at the same time, and the upper layers would then be removed by scorzatura, a process that would destroy any such piece. Hence the pieces resulting from sollevamento sometimes contain unexpected reversals of sequence that are owed to scorzatura. Within a set of fragments that were removed by sollevamento, pieces which were subjected to scorzatura will survive only as a disegno.

As for the Derveni papyrus, the layers in the stacks of fragments, which fill frames II-VII, called B-G by editors (there are also remnants of stacks in frames VIII-IX, but these are even more jumbled), did not adhere to each other. This fact enabled Fackelmann to preserve them. Their sequence, as determined by the sense, shows that he removed pieces now from the front (interior) of the stacks, now from the back (exterior), without any system; sequences of fragments run now forwards, by sollevamento, now backwards, as if by scorzatura, but all the pieces survive, regardless of the sequence in which they were removed or mounted.

If two or more sets of stacks (scorze) are thought to derive from a single roll, their relation to each other must be determined. One needs to try to classify them in terms of whether they come from the same side of the roll or from the opposite side. Similarities in the shapes of different stacks can be tabulated in order to see whether they resemble each other. If they have upper or lower margins, one may be able to find joins in the sense between the end of one column and the beginning of the next. However, these are subject to error, since they depend on a single linkage only. Joins where two halves of a column are in different stacks of scorze are more reliable, since these will have linkages within each line of writing and will yield a complete text. One needs to try 
every possible method for finding joins: matching up photocopies to scale of each piece, examining print-outs of the texts for possible similarities, and so on. The process needs repetition many times, since a change elsewhere in the reconstruction may allow a combination that had at first seemed impossible. One needs to persist until any oddities are resolved. As in the rolls from Herculaneum, pieces from different hemicylinders of the Derveni papyrus need to be arranged alternately in order to recover the original order. If pieces from the same hemicylinder are juxtaposed, the reconstruction must be wrong, as in the first edition of that papyrus. ${ }^{67}$

To establish the position of a piece from a hemicylinder, it helps greatly to know the width of its sezione. However, it is extremely hard to deduce measurements from fragments that are known solely from disegni. ${ }^{68}$ Any extant ultimo foglio must be measured carefully, since in the disegni the draughtsmen spread the letters out for the sake of greater clarity, and did not draw broken edges exactly to scale; one can approximate by counting the number of standard letter-widths and comparing the width of that number of letter-widths on the original. If the column-to-column width can be determined from surviving pieces (see Part I), and the order can be tested by placing the fragments on a model, the distances from one layer to the next must be consistent, as measured from the start of one column to the start of a column in the next circumference; the circumference should always diminish towards the end of the roll. If the number of layers can be determined, the circumferences can yield approximate measurements, and indeed the approximate measurements can help to determine the number of circumferences; however, one must bear in mind that the tightness with which rolls were wound will vary unpredictably, at least at a few points.

Most rolls contain both scorze and a midollo, but in a few cases no midollo has been identified, as in Philodemus' De poematis I. This was reconstructed entirely from six sets of scorze, of which only the ultimo foglio survived in most cases. Let us turn to reconstructing the midolli, and to the tricky problem of how to reconstruct the transition from scorze to midollo.

\section{(b) Reconstructing continuous parts of rolls}

This part of the process of reconstruction might seem straightforward, but in fact has many pitfalls. ${ }^{69}$ First, although a midollo was unrolled continuously, the separate frames (cornici) into which it was cut may 
have had their original order altered. Hayter's system of numbering (A-Z, without J) was used down to I 806 at least; these letters were later replaced by numbers. The letters were also written on the original cartoncini on which the papyri were first mounted. Many papyri, however, were remounted in the I860s on new cornici of blue or white cardboard, numbered in ink under the new system (see Part I). The number of these cornici might differ from the number of original cartoncini. In the case of Philodemus' On Poems 4, the original numeration appeared in pencil on the corners of the new cornici, where they were hidden (as the unfaded blue reveals) under the frames in which the papyri were hung on the wall until I910. $7^{\circ}$

Many rolls have the entire midollo under a single inventory-number, but the midolli of others were unrolled sequentially at various times and received different numbers, as in Philodemus' On Poems 2. Four stretches of papyrus from this roll were given four largely unrelated numbers. Since their dates of unrolling were not clearly recorded in the archives, their relative sequence became clear only via the careful measurement of the sezioni and circumferences; even the sequence of the cornici within each number needs to be confirmed by such measurements.

Constructing a table of fragments and circumferences (Figure I3), in which each fragment is assigned to the correct hemicylinder and to an appropriate circumference (certainty is not always possible), is an essential step towards the reconstruction of the roll; this needs to

\begin{tabular}{|c|c|c|c|c|}
\hline $\begin{array}{l}\text { volute no. } \\
\text { (no. of total } \\
\text { whole } \\
\text { cols.) }\end{array}$ & $\begin{array}{l}\text { next } \\
2 \pi r \\
\text { (est.) }\end{array}$ & $\begin{array}{l}\text { sezione A }(\mathrm{W} .=53.3 \%) \\
\text { (measurements from extant } \\
\text { pieces are bold) }\end{array}$ & sezione $\mathrm{B}(\mathrm{W} .=46.7 \%)$ & $\begin{array}{l}\text { kollesis and distance } \\
\text { to next; actual and } \\
\text { estimated distance; } \\
\text { changes to W. of cols. }\end{array}$ \\
\hline $1(3)$ & 21.0 & $\langle * * *\rangle+<*>/ /$ & $\|\langle *\rangle+\langle * * *\rangle$ & $?$ \\
\hline $2(6)$ & 20.9 & $\begin{array}{l}1081 \text { b fr. } 23 \text { (olim fr. B12) } \\
1677 \text { a fr. } 12(\text { olim fr. } 1 ?)+ \\
1081 \text { b fr. } 20 \text { (olim fr. B11) } \\
<^{*}>/ / 20.9\end{array}$ & $\begin{array}{l}/ /<*>+994 \text { cr. } 1 \text { fr. Ba } ~ \\
<* * *>\end{array}$ & $?$ \\
\hline $3(9)$ & 20.6 & $\begin{array}{l}1081 \text { b fr. } 17 \text { (olim fr. B 10?) + } \\
\text { fr. } 15 \text { (olim fr. B9)// }\end{array}$ & $\begin{array}{l}\left./ /<^{*}\right\rangle+994 \text { cr. } 1 \text { fr. } \mathrm{Bb} \sim \\
1677 \text { a fr. } 3 \text { col. i }(\text { olim fr. } \\
\left.2)+<^{*}\right\rangle \sim \text { col. ii } / / \mathbf{2 2 . 0} \text { ? }\end{array}$ & $?$ \\
\hline $4(11)$ & 20.5 & $/ /<*>+\langle *\rangle / /$ & $\begin{array}{l}\|<*>+994 \text { cr. } 1 \text { fr. Bc } ~ \\
<*>/ /\end{array}$ & $?$ \\
\hline$\ldots$ & $\ldots$ & $\ldots$ & $\ldots$ & $\ldots$ \\
\hline $100(195)$ & 7.9 & 994 col. 13// 7.9 & //994 col. $13+$ col. $14 / /$ & $\begin{array}{l}994 \text { col. } 13 \text { litt. } 3: \\
16.0 \text { to next }\end{array}$ \\
\hline $101(196)$ & 7.8 & //994 col. 14// 7.8 & $/ / 994$ col. $14+$ col. $15 / /$ & none \\
\hline 102 (197) & 7.7 & //994 col. 15// & $\begin{array}{l}/ / 994 \text { col. } 15+\text { col. } 16 / / \\
\mathbf{7 . 6}(\text { cr. } \mathbf{1 4})\end{array}$ & $\begin{array}{l}994 \text { col. } 15 \text { litt. } 9: \\
16.2 \text { to next }\end{array}$ \\
\hline $103(198)$ & 7.5 & //994 col. 16// & $/ / 994$ col. $16+$ col. $17 / /$ & none \\
\hline
\end{tabular}

Figure 13. Extracts from table of layers and circumferences in Philodemus' On Poems 2 (R. Janko) 
contain a calculation by dead reckoning of the expected circumferences, together with a record of the circumferences that have been reliably measured. It must be kept in mind that the length of the circumference diminishes even within a single circumference. Since the column-tocolumn width, as measured from the left margins of successive columns, is nearly always fixed, whereas successive circumferences must decline by a smaller or occasionally a larger amount, Essler used the relation between successive circumferences and the left edges of columns to calculate, using modular arithmetic, the probability that successive left edges belong to successive circumferences. ${ }^{71}$ His spread-sheet by which that probability is calculated is a valuable tool for reconstruction (Figure I4). $7^{72}$

If the exact circumference is not known, it can be extrapolated from circumferences further away. The reduction in successive circumferences is necessarily limited by the thickness of the material of which the scroll is made; each circumference must decline by an amount given by the

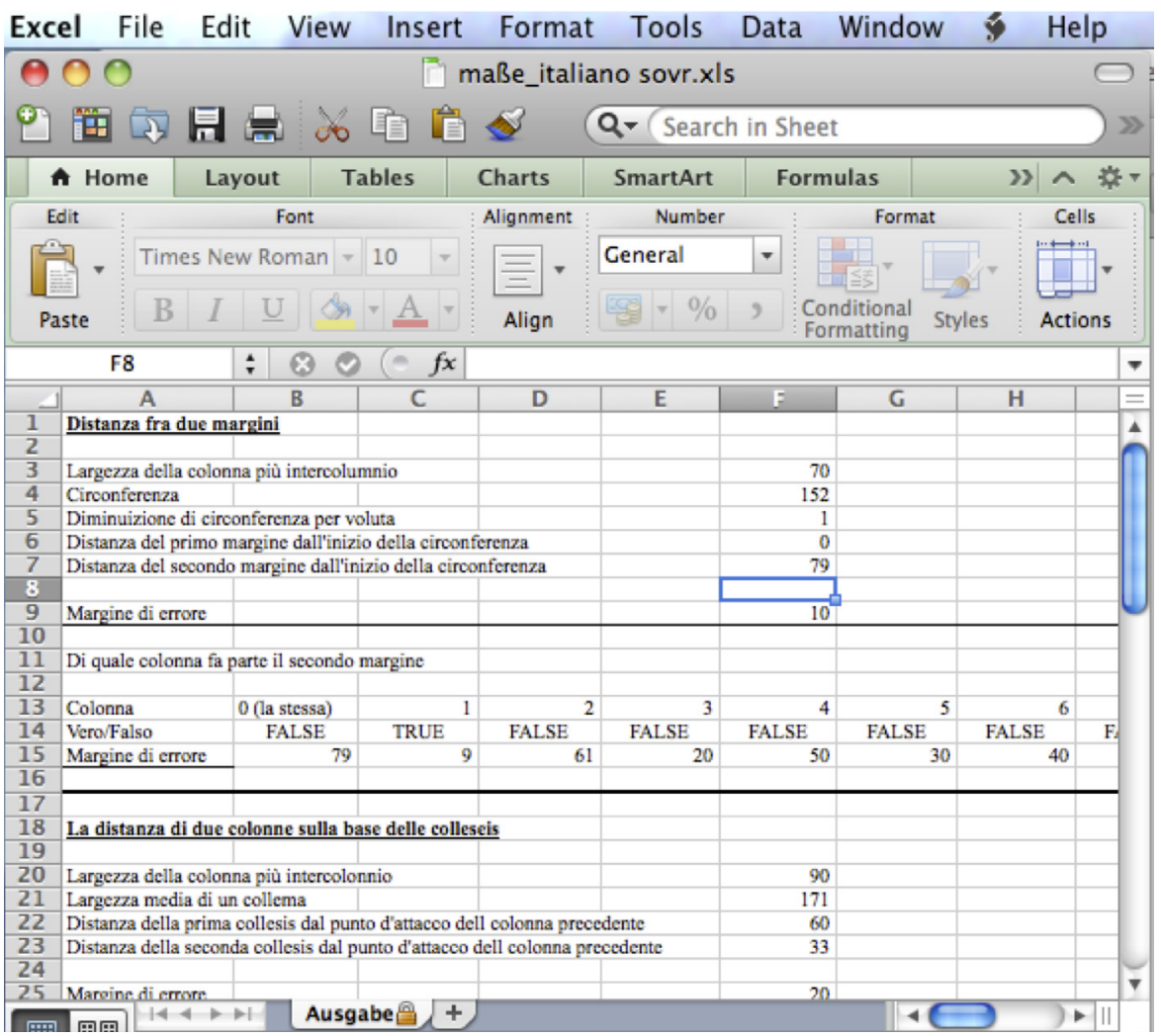

Figure 14. Example of the use of Holger Essler's spread-sheet based on modular arithmetic (photo R. Janko) 
mathematical formula $\delta \geq 2 \pi t$, where $\delta$ denotes the decline and $t$ denotes the thickness of the material (normally 0.1 $5 \mathrm{~mm}$ ). ${ }^{73}$ Experiments with models and verified actual examples show that the decline remains fairly constant except for a few wildly greater declines, where a single spiral was wound much more loosely.

Exact measurement of the circumference is also vital for placing (frammenti) sottoposti ('pieces placed under') and sourapposti ('pieces placed over'), which range in size from part of a single letter (Figure 3) to a large piece of text (Figure I 5). ${ }^{74}$ These occur both in the originals and (sometimes) in the disegni, and also appear in the Derveni papyrus, albeit rarely. They are pieces of a layer other than the main one that is visible: sottoposti are displaced pieces of a previous circumference, which may be seen to run under the main layer; sourapposti are pieces of a later circumference, which sometimes visibly overlie the main layer. These are terribly hard to detect. Some claim that they can always see them even in the multispectral images, which of course are two-dimensional. In my experience, however, they are best seen only in the original three dimensions, and even there one often has trouble deciding whether they lie under or over the main layer. I always test both possibilities for placing them, and often find that apparent sourapposti are in fact sottoposti and vice versa.

Knowing the circumference of the roll at any given point, a difficult task, is vital for placing such fragments, especially those that are tiny,

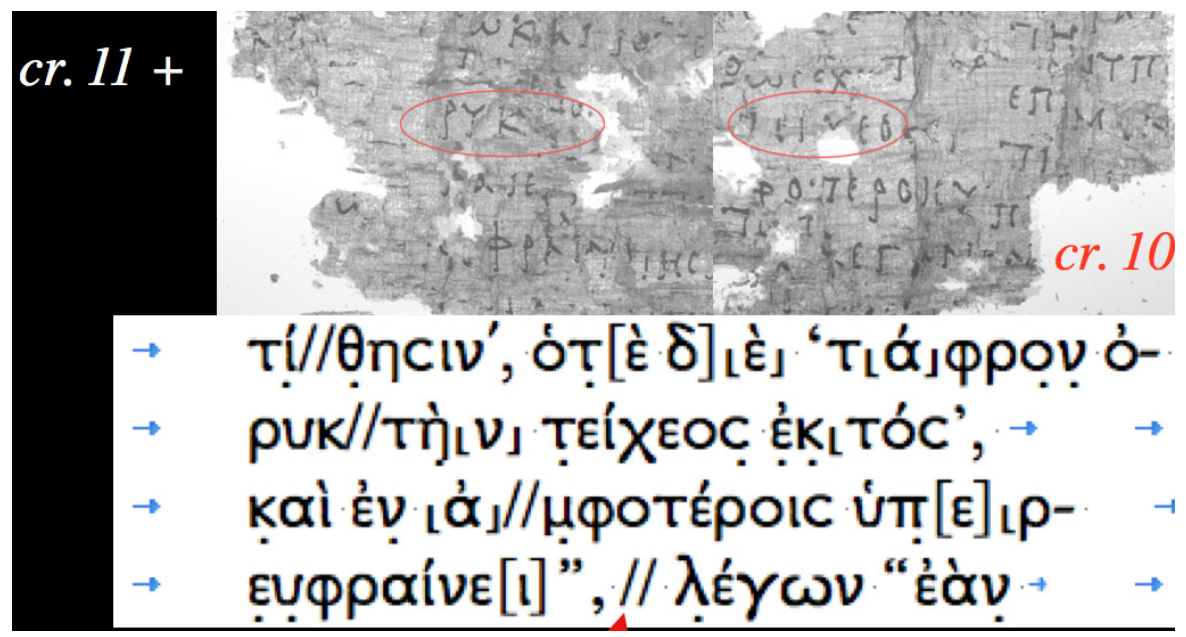

Figure 15. Join between sottoposto and sovrapposto in P. Herc. 994 crr. Io and I I (photos Brigham Young University/B.N.N., copyright, all rights reserved) 
as is most often the case. Conversely, finding and placing them can determine the circumference. Extraneous letters should always be checked against the text roughly one circumference earlier and one circumference later. If they fit, they provide the most exact measurement of the circumference imaginable. Extraneous letters are not always from the previous or succeeding circumference, but may have originated several circumferences away. However, it is very difficult to find the location of such letters at a distance of more than one circumference, since the measurements are rarely exact enough. Also, I have hardly ever managed to place them across a break between cornici, because the cut makes it hard to be sure of the exact height on the other side, even though the letters must belong at almost exactly the same height in the adjacent circumference; rolls were never wound diagonally.

Sovrapposti and sottoposti were sometimes transcribed from the original papyrus into the disegni, and these can be very helpful for reconstruction; if extraneous letters appear in disegni that are not now in the original, they are normally sovrappost $i$ which have since fallen away and perished. If the circumference is known, the letters may be found to belong one or two circumferences later. Conversely, if a disegno offers a coherent text that is now interrupted in the original by extraneous letters, the latter are probably preserved on a sottoposto which has only become visible since the disegno was made. These phenomena also appear in old photographs of the papyri. They lie at the origin of the myth, or rather the suspicion propagated by scoffers and sceptics, that letters appear and disappear in the Herculaneum papyri according to papyrologists' wishes; in reality letters only disappear, as the papyri slowly disintegrate, and the 'new' ones replace only in appearance those that have actually vanished for ever.

The presence of a kollesis can prove or refute the placing of upper or lower fragments that are broken horizontally; the line of the kollesis should run vertically through both fragments. The same test may apply to the crack that precedes the kollesis (see Part I). Once successive kolleseis have been found, the distance between each one and the next needs to be determined as exactly as possible. These widths can be used to calculate the average width of all the kollemata observed in the roll (Figure I6). ${ }^{75}$ The widths of kollemata vary considerably, even within a single roll, but they are nonetheless a useful indication as to whether the reconstruction is correct. Like column-to-column widths, kollemata vary in their incidence with regard to the successive circumferences. Hence modular arithmetic can be used to calculate the probability that 


\begin{tabular}{|c|c|c|c|c|c|}
\hline 994 cr. 15 며 & $49 \mathrm{~A}^{\not}$ & start & col. 23 litt. 12 & 2.8 to right ${ }^{\text {म }}$ & $2.8+12.4=15.0$ \\
\hline $994 \mathrm{cr} \cdot 16^{\text {口 }}$ & $49 \mathrm{~B}$ म & end & col. 25 litt. $16^{\text {a }}$ & 12.4 from left & $2.8+12.4=15.0$ \\
\hline 994 cr. $16^{\text {마 }}$ & $50^{\text {吕 }}$ & whole & $\begin{array}{l}\text { col. } 25 \text { litt. } 16- \\
\text { col. } 27 \text { litt. } 16^{-}\end{array}$ & 14.5 म & 14.5 \\
\hline 994 cr. $16^{\text {t }}$ & $51 \mathrm{~A}^{2 \pi}$ & start ${ }^{\text {ta }}$ & col. 27 litt. 16 & $1.0-1.5$ to right & $1.5+14.9=16.4$ 맘 \\
\hline 994 cr. 17 & $51 \mathrm{~B}^{\square}$ & end ${ }^{\not}$ & col. 30 litt. 4 & 14.9 from left & $1.5+14.9=16.4$ \\
\hline 994 cr. 17 可 & 52 म & whole & $\begin{array}{l}\text { col. } 30 \text { litt. } 4- \\
\text { col. } 31 \text { litt. } 7 \text { म }\end{array}$ & $\begin{array}{l}15.7 \text { (with lost } \\
\text { layer) }\end{array}$ & 15.7 म \\
\hline 994 cr. 17 마 & $53 \mathrm{~A}^{\text {म }}$ & start ${ }^{2}$ & col. 31 litt. 7 & 3.8 to right & $3.8+12.0=15.8$ \\
\hline $994 \mathrm{cr} \cdot 18$ 마 & $53 \mathrm{~B}$ 마 & end & col. 33 litt. 14 & 12.0 from left & $3.8+12.0=15.8$ \\
\hline 994 cr. 18 可 & 54 픔 & whole & $\begin{array}{l}\text { col. } 33 \text { litt. } 14- \\
\text { col. } 35 \text { litt. } \\
19+2\end{array}$ & 16.0 म & 16.0 \\
\hline 994 cr. 18 可 & $55 \mathrm{~A}^{\not 2}$ & start & $\begin{array}{l}\text { col.35 litt. } \\
19+2\end{array}$ & 0.2 to right & $0.2+\langle 0.5\rangle+15.0 \approx 15.7$ \\
\hline 994 cr. 19 可 & $55 \mathrm{~B}^{\text {口 }}$ & end $^{x}$ & col.38 litt. 3 & 15.0 from left ${ }^{\text {म }}$ & $0.2+\langle 0.5\rangle+15.0 \approx 15.7$ \\
\hline 994 cr. 19 므 & $56 \mathrm{~A}^{\text {म }}$ & start & col. 38 litt. 3 맘 & 13.4 to right & $13.4+2.3=15.7$ 마 \\
\hline 994 cr. $2^{\text {口 }}$ & $56 \mathrm{~B}^{\text {口 }}$ & end ${ }^{\text {म }}$ & in agraphon & 2.3. from left ${ }^{\text {म }}$ & $13.4+2.3=15.7$ \\
\hline 994 cr. 2 & 57 吕 & start & in agraphon & 10.5 to right & $10.5+$ (incomplete) $^{2}$ \\
\hline 石 & Ix & II & 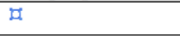 & 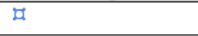 & average $=274.4 \div 17=16.1$ \\
\hline E & 무 & 문 & $\not$ & $\not$ & maximum $=17.8$ \\
\hline I & I & 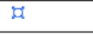 & a & I & minimum $=14.5$ \\
\hline
\end{tabular}

Figure 16. Extract from table of measurements of kollemata in Philodemus' On Poems 2 (R. Janko)

a particular kollesis falls within the next circumference, again using Essler's spread-sheet, which has a setting for this calculation. However, the probabilities provide less precision than in the case of column-tocolumn widths.

Stichometry, i.e. the numerals that the scribes employed to verify the number of lines or columns that they had copied, is, where it exists, a valuable check on the reconstruction of the roll. ${ }^{6}$ Not all rolls have stichometry, and it can take different forms. Column-numbers may appear in the upper margins, perhaps with the total of the number of columns ( $\sigma \varepsilon \lambda i \delta \varepsilon \varsigma)$ at the end of the manuscript; these are easy to interpret. ${ }^{77}$ It is more usual to find stichometric signs in the left margins, together with a stichometric total at the end of the roll, introduced by the abbreviation $\dot{\alpha} \rho t \theta(\mu o ́ s)$ and written in the Attic system of acrophonic numerals. The signs comprise the Greek alphabet of twenty-four letters (or twentyfive, if, as occasionally seems to happen, the digamma is included). If more signs are needed, the series of letters is repeated, starting again with alpha. They often have horizontal bars over them, under them, or in both positions. There may also be stichometric points, i.e. dots in the left margins at regular intervals: each interval corresponds to ten stichoi. Since a stichos was originally the length of a hexameter, and prose texts at Herculaneum are written in shorter lines about half as long as that, 
one cannot simply convert the number of lines in the papyrus into stichoi or vice versa: the conversion factor must be determined.

The first step towards using stichometry for reconstruction is to find it. Margins must be scanned closely for signs, though often all they yield is marks where the scribe tested his pen. Sometimes, despite one's best efforts, only a couple of signs can be found. But even these can suffice for the reconstruction of an entire roll.

The next step is to determine the interval between signs. The usual interval in prose texts written in narrow columns of $18-20$ letters is I 80 or 200 ; this number was deemed to equal Ioo stichoi or hexameter verses. If the full height of the roll is preserved, the interval can be discovered without difficulty. If stichometric points are used, they will appear every ten stichoi; so the interval will be the number of lines which separates two successive points multiplied by ten. Even if the bottom or top of the roll has perished, so that the number of lines per column is unknown, all is not lost, since even a few signs provide more fixed points on which to base calculation than one would expect. The start of the roll, even if lost, remains of course line I, and the end of the roll, if reasonably intact, provides another fixed point. Simultaneous algebraic equations can be created to solve the problem. ${ }^{7}$ Different solutions to the equations can be tested in a spread-sheet into which one can insert varying intervals between signs and different average numbers of lines per column. Even though the number of lines per column will fluctuate slightly, most of these tests will predict that stichometric signs will occur at places where one is certain that they do not; by elimination, the correct number of lines per column can be found. ${ }^{79}$ Philodemus' On Poems 4 was an especially illuminating case, since for a long time the stichometry made no sense. Eventually David Blank proved to me that an irregularity in the column-to-column width, where there seemed to be an exceptionally wide intercolumnium, was in fact no such thing, but rather a place where a whole column was lost under the next one; because the overlap occurred in successive intercolumnia, where there were no letters running under the next circumference, the transition between layers was almost completely invisible. Once the lost column was posited, the stichometry was quickly solved with algebra. ${ }^{80}$

Stichometry can readily be used to calculate the original number of columns in the complete roll and its original length, and to check and solidify the entire reconstruction. The stichometry can be compared with the number of observed columns (which can be multiplied by the column-to-column width), the number of kollemata (multiplied by their 
average or total width), the cumulative sum of the circumferences as they have been measured or posited, and the physical widths of extant pieces of papyrus to determine whether, and where, any lost columns and missing circumferences may lie. When the unrollers of Herculaneum papyri lost the leading edge, they sometimes had to cut away layers of papyrus that could contain quite a number of columns. Earlier editors were often unaware of such losses, which can now be determined quite exactly. Careful attention to all these aspects of the material support of our texts permits them to be reconstructed with hitherto unimagined exactitude. The work is laborious in many respects, but does pay off. To determine the length of the entire roll, one must make allowance for the titles and unwritten portions at the end, and allow the same amount for those at the beginning, which is almost always lost. ${ }^{81}$

Lastly, other features internal to the texts themselves can contribute to their reconstruction, such as gradual changes in the number of letters per line or in the number of lines per column, the presence of a second scribal hand for a certain portion of the papyrus, the presence for a stretch of a few columns of notes or accents added by a reader (this appears in On Poems I), or the series of textual parallels between summaries and rebuttals of opponents such as Philodemus often employs: for example, the summary and rebuttal on On Music 4 or the summary in On Poems I that is rebutted at the end of the book, continuing throughout On Poems 2. ${ }^{82}$ Which features are present will vary according to the idiosyncrasies of the particular text, but one needs to watch out for them.

My own system for reconstruction, which I learned from Daniel Delattre, ${ }^{83}$ is to build a paper model of the entire roll at its actual size, using print-outs of the digital images where available, and otherwise print-outs of images of the disegni, both adjusted to the correct scale (Figure 17). These materials are fastened with small pieces of plastic tape to a long roll of paper, put together from separate sheets by using the same plastic tape. The tape must be of the kind that can be torn off or removed without damaging the surface to which it lightly adheres; never use glue. The backing has drawn on it in pencil column-to-column widths to serve as a guide and a first indication of errors in placement. If necessary, the roll can readily be shortened or lengthened at any given point by inserting more paper backing, in quantities that correspond to the column-to-column width. The model needs to be stretched out on a table at least two metres long in front of a large window (the trailing ends of the scroll can be allowed to fall into cardboard boxes on the floor at either end). Good light is essential; sunlight reflected off 


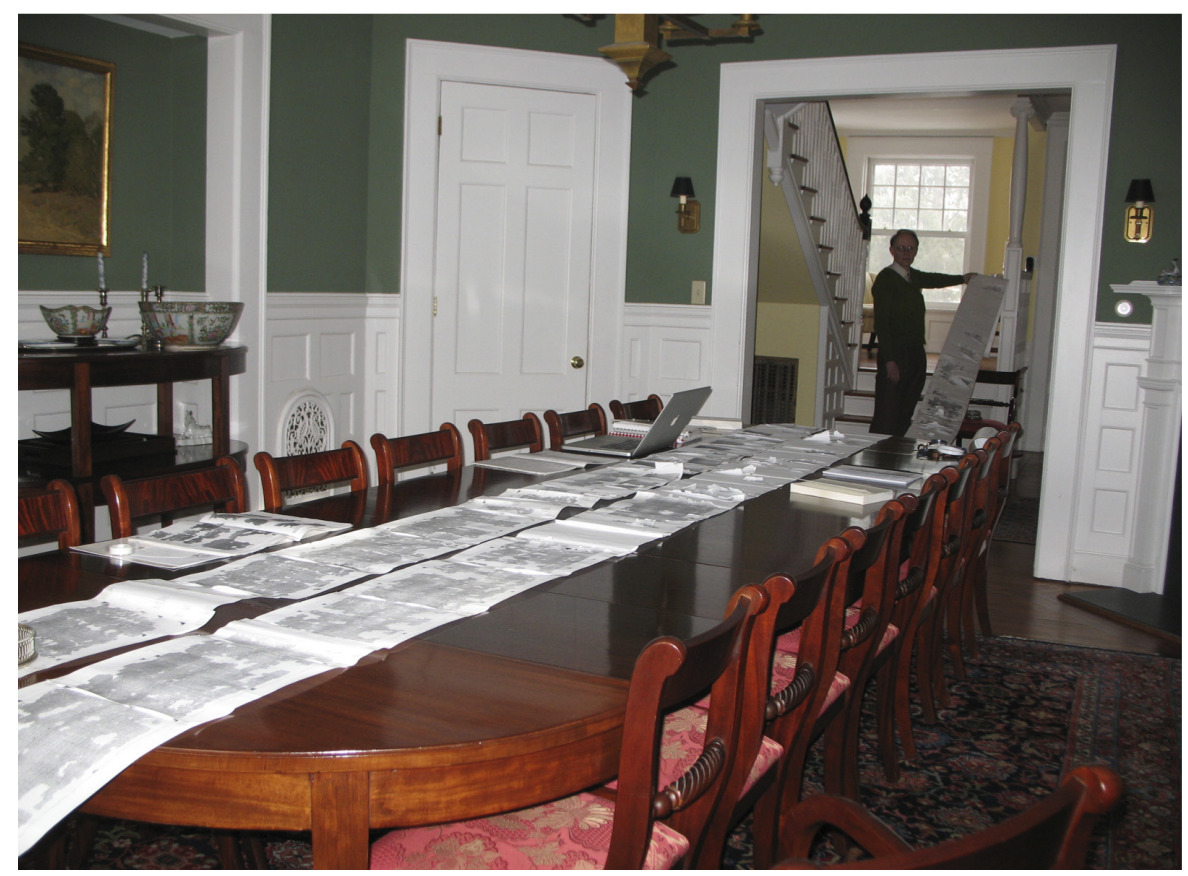

Figure 17. Paper model of Philodemus' On Poems 2, length I $6 \mathrm{~m}$ (photo M. Hannoosh)

snow is best. The model can be rolled, stored and transported in a stiff cardboard tube.

Applying all the principles explained above, one starts with an initial guess, laying out the pieces in what one deems the most likely order. Many problems will at once appear - fragments that cannot join, columns that do not fit into the regular spacing of the column-to-column widths, and so on. By constantly striving to better the text, and by constantly trying different combinations of pieces, one gradually improves the model. The hardest steps are probably two.

The first is to manage the transition between the initial part preserved only in disegni and the extant pieces of papyrus. This can be very awkward, since an error of only one column can prevent one from integrating the two segments. Often the mistake lies in a confusion as to which hemicylinder (sezione) in the segment preserved only in disegni corresponds to the same hemicylinder in the extant portion. One must always test the other possibility, even if it seems to be wrong.

Secondly, the final decision that the model is correct is a source of great procrastination and anguish. ${ }^{84}$ One's edition can only be finished once it has final column-numbers, but during the reconstruction 
these continue to change; in draft texts, I mark column-numbers with footnote-numbers that adjust automatically, until the reconstruction is stable. But how can one ever be sure that the reconstruction is right, and apply these final column-numbers? One is never entirely sure, and our work in this challenging field must always be deemed probable rather than certain; but when repeated rearrangements yield impossibilities of the same kind, when work on the text itself seems subject to the law of diminishing returns, when all the calculations outlined above (or as many of them as can be applied) have been done and yield consistent results, and when the imposition of this particular arrangement keeps yielding good textual continuity, it is time to... work on a different project for a while, and to pause before accepting the column-numbers as final. For once these numbers are in the text, everything else, including crossreferences, the discussion of the papyrus and its language and content in the introduction, and the index verborum, will depend on them and will be fixed. Thereafter the numbers can no longer be changed without immense and ungrateful labour. Thus it is always with a heavy heart and deep foreboding, and not with any feeling of triumph or even satisfaction, that I conclude that the numeration of the columns is stable enough to be adopted for my edition, and at last insert the final columnnumbers into the index verborum.

As Vergil feelingly put it, labor omnia vincit I improbus. Only when clad in an armament of unremitting effort and the magic of numbers, harnessing fire-breathing bulls and facing down armed skeletons left and right, can one plough the field of these papyri and reap their harvest of new texts.

\section{Notes}

I. The closest analogues are M. Capasso, Manuale di papirologia ercolanese (Galatina, I99I), pp. 229-236, and D. Delattre, La Villa des Papyrus et les rouleaux d'Herculanum. La Bibliothèque de Philodème (Liège, 2006), neither in English. D. Sider, 'The Special Case of Herculaneum', in The Oxford Handbook of Papyrology, ed. by R.S. Bagnall (Oxford and New York, 2009), pp. 303-3 I9, admits some inaccuracies (pp. 306-3 Iо). I. Gallo, 'The Herculaneum Papyri', in Greek and Latin Papyrology, transl. M.R. Falivene and J.R. March, Institute of Classical Studies (London, I986), pp. 36-45, has a very basic account. W.A. Johnson, Bookrolls and Scribes in Oxyrhynchus (Toronto, 2004), does not treat Herculaneum papyri, but provides much invaluable comparative material from Oxyrhynchus. E.G. Turner, Greek Papyri: an Introduction (2nd edn, Oxford, I980) did not 
even list $P$. Herc. among abbreviations for papyri, and his first edition (I973) ignores carbonized papyri.

2. On these see Delattre, La Villa des Papyrus, pp. 26-27.

3. The Johannowsky papyrus from Thmouis in the Nile delta, also kept in the Officina dei Papiri, is likewise mounted on a cornice without glass: see G. Del Mastro, 'Il papiro Johannowsky: un papiro di Thmouis?', Aegyptus, 90 (2010), 23-36. Like the other tax-rolls from Thmouis, it is preserved flat; this fact renders these papyri more readily legible than other carbonized ones, and it will be reconstructed like non-carbonized tax-rolls.

4. E.g. the tax-roll in Strasbourg from Hermoupolis that has been cut into sections: see R.-L. Chang, Un dossier fiscal hermopolitain d'époque romaine (P. Stras. inv. gr. 897-8, 903-5, 939-68, 982-1000, IOIO-13, I918-29): édition et commentaire (IFAO, Cairo, forthcoming).

5. See also Delattre, La Villa des Papyrus, pp. I02-105.

6. On the role of the CISPE see Delattre, La Villa des Papyrus, pp. Io9, I33-I34.

7. V. Litta, I papiri ercolanesi II. Indice topografico e sistematico, Quaderni della Biblioteca Nazionale di Napoli IV. 6 (Naples, I977), has been replaced by A. Travaglione, Catalogo descrittivo dei Papiri Ercolanesi (Naples, 2008); both are held in the Officina.

8. M. Gigante, Catalogo dei Papiri Ercolanesi (Naples, I979).

9. M. Capasso, 'Primo supplemento al Catalogo dei Papiri Ercolanesi', Cronache Ercolanesi, I9 (I989), I93-264; G. Del Mastro, 'Secondo supplemento al Catalogo dei Papiri Ercolanesi', Cronache Ercolanesi, 30 (2000), I 57-24I.

Io. For a description of the Officina see Delattre, La Villa des Papyrus, pp. I06-109.

II. On the unrolling see Capasso, Manuale, pp. 88-i 18; A. Angeli, 'Lo svolgimento dei papiri carbonizzati', Papyrologia Lupiensia, 3 (I994), 37-I04; Delattre, La Villa des Papyrus, pp. 29-39.

I 2. On their conservation see Delattre, La Villa des Papyrus, pp. 25-27.

I3. H. Essler, 'Bilder von Papyri und Papyri als Bilder', Cronache Ercolanesi, 36 (2006), IO3-I43 (pp. IO3-I27).

I4. Even the new cartoncini have been replaced in cases where Fackelmann or Kleve remounted the pieces, but these have been preserved.

I 5. A. Fackelmann, 'The Restoration of the Herculaneum Papyri and Other Recent Finds', BICS, I7 (I970), I44-I45; Capasso, Manuale, pp. I Io-I I 2. The earlier backings are kept in the Officina. 
I6. His report on his restoration of that papyrus is published in T. Kouremenos, G.M. Parássoglou and K. Tsantsanoglou, The Derveni Papyrus (Florence, 2006), pp. 4-5.

I 7. Its operative end must be prevented from scratching the glass by a ring of soft plastic foam. Similar microscopes in the near-infrared spectrum are also invaluable (see R. Janko, 'Parmenides in the Derveni Papyrus: New Images for a New Edition', ZPE, 200 (20I6), I-2I.

I 8. B. Fosse, K. Kleve and F.C. Störmer, 'Unrolling the Herculaneum Papyri', Cronache Ercolanesi, I4 (I984), 9-I5; Capasso, Manuale, pp. II2-II6; Delattre, La Villa des Papyrus, pp. I Io-I I2. As the method is invasive, it has been abandoned.

I9. On the drawings see Capasso, Manuale, pp. I I9-I 28.

20. The shelf-mark is Ms. Gr. class. c. 2. They were catalogued by W. Scott, Fragmenta Herculanensia (Oxford, I 885 ).

2I. For the characteristics of these see M. Capasso, 'Per la storia della papirologia ercolanese III: il Piaggio a lavoro', in Bicentenario della morte di Antonio Piaggio, ed. by M. Capasso (Galatina, I997), pp. 61-76, showing that Piaggio's drawings contained multiple columns; R. Janko, 'New Fragments of Epicurus, Metrodorus, Demetrius Laco, Philodemus, the "Carmen De Bello Actiaco" and Other Texts in Oxonian Disegni of I788-I792', Cronache Ercolanesi, 38 (2008), 5-95.

22. There is a set of good images of them on the internet at the website of the Herculaneum Society.

23. Ms. Clar. Press d. 44. On Davy's activities see F. Longo Auricchio, 'L'esperienza napoletana del Davy', in Proceedings of the XIXth International Congress of Papyrology, ed. by A.H.S. El-Mosallamy (Cairo, I992), pp. I 89-202.

24. Royal Collections Inventory No. I076I70.

25. Study of these unpublished disegni has begun (Guay and Janko in progress). They depict parts of P. Herc. 59, 97, I77, 24I, 37 I, 373, 396, 494, 495, 502, $8 \mathrm{II}, \mathrm{II} 38, \mathrm{I} 484, \mathrm{I} 620$, and I67I. Of these, 396, 502, I484 and I620 are in Latin, and the rest are in Greek.

26. This procedure was introduced when the Accademia Ercolanese was refounded in 1787 .

27. R. Janko, with D.L. Blank, 'Two New Manuscript Sources for the Texts of the Herculaneum Papyri', Cronache Ercolanesi, 28 (I998), I73-I84; R. Farese, 'Catalogo degli “illustrazioni” e degli interpreti', Cronache Ercolanesi, 29 (I999), 83-94.

28. Ms. Gr. class. c. 2, vol. 8. 
29. Images of $H V$ are available on the website of the Herculaneum Society.

30. Shelf-mark III 4II.5OI; cf. R. Janko, Philodemus: On Poems Book One (Oxford, 2000), p. 40.

3 I. J. Hammerstaedt, 'Christian Jensen's and Wolfgang Schmid's Unpublished Herculanean Papers', in Proceedings of the XXVth International Congress of Papyrology, ed. by T. Gagos (Ann Arbor, 20I0), pp. 29I-298; R. Janko, ed., Philodemus On Poems Books Three and Four, with the Fragments of Aristotle On Poets (Oxford, 20I I), pp. I 5 5-I 57.

32. On photography of the papyri see Capasso, Manuale, pp. I42-I 48 .

33. Janko, 'Parmenides in the Derveni Papyrus'.

34. S.W. Booras and D.R. Seely, 'Multi-Spectral Imaging of the Herculaneum Papyri', Cronache Ercolanesi, 29 (I999), 95-I00; Delattre, La Villa des Papyrus, pp. II3-II6.

35. For similar cautions see Delattre, La Villa des Papyrus, p. I I 5.

36. Cf. Johnson, Bookrolls, pp. 9I-98.

37. Cf. ibid., pp. го०-г I 8.

38. The principle of sezioni was discovered by M.L. Nardelli, 'Ripristino topografico di sovrapposti e sottoposti in alcuni papiri ercolanesi', Cronache Ercolanesi, 3 (I973), IO4-II I.

39. M. Capasso, Volumen: aspetti della tipologia del rotolo librario antico (Naples, I995), pp. 73-98; Delattre, La Villa des Papyrus, pp. 4I-42. The Derveni papyrus too must already have had such a rod, which was $c .1 .2 \mathrm{~cm}$ in diameter (Janko, 'Parmenides in the Derveni Papyrus').

40. Cf. Johnson, Bookrolls, pp. 88-9I.

4I. For these rules see Janko, Philodemus: On Poems Book One, pp. 75-76.

42. I owe this technique to Jim Porter. Now, however, bold type is beginning to be used for letters transposed from a different layer. These are best left in the old convention, i.e. $/ / \alpha / /$, at least until the text is ready for publication.

43. Usener's Glossarium Epicureum and Vooys' Lexicon Philodemeum, rare works available only in exceptional libraries, are invaluable resources for Herculaneum papyri in particular. The references are keyed, respectively, to $H V$ and to old Teubner editions of Philodemus, which also need to be to hand. The index to Sudhaus' edition of Philodemus' Rhetoric is useful too, not to mention the indices verborum of more recent editions.

44. Philodemus' works are still so inchoate that most are not included in the TLG. A draft of a digital version of his texts created for the TLG was made available to the Philodemus Translation Project. A version of it without 
diacritics, dots and brackets has proved extraordinarily useful for finding supplements, along with a version with even the spaces removed.

45. M. McOsker, 'The Number of Papyrus Rolls Excavated from the Villa dei Papiri: Some Overlooked Evidence', Cronache Ercolanesi, 46 (2016).

46. Janko, 'New Fragments of Epicurus', showing that the worst confusion among the numbers occurred in $c$. I790.

47. See Delattre, La Villa des Papyrus, pp. I30-г 3 I.

48. D.L. Blank, 'Reflections on Rereading Piaggio and the Early History of the Herculaneum Papyri', Cronache Ercolanesi, 29 (I999), 55-82; Delattre, La Villa des Papyrus, p. 32.

49. See D.L. Blank and F. Longo Auricchio, 'An Inventory of the Herculaneum Papyri from Piaggio's Time', Cronache Ercolanesi, 30 (2000), I3 I-I47, and for the exact date Janko, Philodemus: On Poems Book One, p. 8 n. I.

50. Their dimensions are given in old Neapolitan palme and oncie, where one palma $=26.37 \mathrm{~cm}$ and one oncia $=2.1976 \mathrm{~cm}$. The first part of the catalogue is still undiscovered.

5I. The introduction to my edition of Philodemus' On Poems 2 (Janko, in preparation) will contain an analytical table of all the papyri that were opened down to 1796.

52. Blank and Longo Auricchio, 'An Inventory'. Those which do not follow numerical order list the papyri in relative order of unrolling. The 'Nota di tutti i disegni de' papiri d'Ercolano svolti, e questi col numero secondo si trovano segnati nell'inventario' (ibid., pp. I33-136), a draft which is in the Bodleian Library (Ms. Gr. class. c. Io, f. 36), was written on 2 Sept. I 807, as is known from the fair copy in the Archivio di Stato di Palermo (Reale Segreteria fasc. 55 I 2). Its only notable variants are that entry 908 records 'frammenti Latini' instead of 'frammenti Greci', and 994 lists 'Disegni diecisette' rather than 'Disegni trentasette'.

53. Archivio dell'Officina dei Papiri (A.O.P.) XVII I I, listing 1756 items.

54. A.O.P. XVII I 2; for its authorship see Janko, Philodemus: On Poems Book One, p. I4 n. I.

55. A.O.P. XVIII I3.

56. H. Essler, 'X $\mathrm{XPIZEIN} \mathrm{AX \Omega PI \Sigma TA.} \mathrm{Über} \mathrm{die} \mathrm{Anfänge} \mathrm{getrennte}$ Aufbewahrung der Herkulanischen Papyri', Cronache Ercolanesi, 40 (2010), I73-I89; he publishes all the relevant data down to March I802, but only some thereafter.

57. See Capasso, Manuale, pp. 245-252; A. Travaglione, 'Incisori e curatori della Collectio Altera. Il contributo delle prove di stampa alla storia dei 
papiri ercolanesi', in Contributi alla Storia della Officina dei Papiri, iii, ed. by M. Capasso (Naples, 2003), pp. 87-I78. There is no convenient database of the personnel, published or unpublished. Editions by myself and others provide information piecemeal on those people whom we have encountered, e.g. that Pessetti was dismissed as interprete in I 8 I I, Caterino was appointed in I 8 I 2, Genovesi in I 822, Ottaviano and Quaranta in I 826, and Lucignano in $\mathrm{I} 832$. Since posts at the Officina were treated more or less as hereditary or as a family business, many employees share surnames, which can complicate matters.

58. See further G. Houston, Inside Roman Libraries: Book Collections and Their Management in Antiquity (Chapel Hill, 2014), pp. 87-I29, 280-286.

59. G. Del Mastro, Chartes. Catalogo Multimediale dei Papiri Ercolanesi (Naples, 2005).

6o. R. Janko, 'Reconstructing (again) the Opening of the Derveni Papyrus', ZPE, I66 (2008), 37-5I.

6r. On the method see Delattre, La Villa des Papyrus, pp. I I6-i I9.

62. A. Schober, 'Philodemi De pietate pars prior', diss. Königsberg, I923, pr. in Cronache Ercolanesi, I8 (I988), 65-I25.

63. D. Delattre, 'Philodème, De la musique: livre IV, colonnes 40" à I09", Cronache Ercolanesi, I9 (I989), 49-I43.

64. D. Obbink, Philodemus: On Piety Part I: Critical Text with Commentary (Oxford, I996).

65. A.O.P. XVII Io. There is also the 'Notamento de' rami incisi' of I 840 (A.O.P. XVII I 5 ). Neither is published.

66. Janko, Philodemus: On Poems Book One, pp. I9-20; Delattre, La Villa des Papyrus, pp. 32-33.

67. Janko, 'Reconstructing'.

68. Cf. Delattre, La Villa des Papyrus, pp. I20-I 2 I.

69. Ibid., pp. І 2 I-І 30.

70. Essler, 'Bilder', I03-I 27.

7I. H. Essler, 'Rekonstruktion von Papyrusrollen auf mathematischer Grundlage', Cronache Ercolanesi, 38 (2008), 273-307.

72. This is available upon application to Prof. Essler.

73. See Janko, Philodemus: On Poems Book One, pp. Io8-I09; Janko, Philodemus On Poems Books Three and Four, pp. 43-46, with a formula for calculating the length of the scroll based on its diameter. On the length of rolls 
see Janko, Philodemus: On Poems Book One, pp. I I 8-i I9; Delattre, La Villa des Papyrus, pp. 50-5I.

74. On their importance see Delattre, La Villa des Papyrus, pp. I I9-I2 I.

75. Capasso, Volumen, pp. 55-72; Delattre, La Villa des Papyrus, pp. 48-49.

76. For stichometry see K. Ohly, 'Die Stichometrie der Herkulanischen Rollen', Archiv für Papyrusforschung, 7 (1924), I90-220 and Stichometrische Untersuchungen (Leipzig, I928); Obbink, Philodemus: On Piety, pp. 62-63; Delattre, La Villa des Papyrus, pp. 44-48.

77. Delattre, La Villa des Papyrus, pp. 49-50.

78. For examples of such calculations see Janko, Philodemus: On Poems Book One, pp. I I4-i 8; Janko, Philodemus On Poems Books Three and Four, pp. I98-207.

79. Janko, 'Parmenides in the Derveni Papyrus', on the stichometry of the Derveni papyrus.

80. Janko, Philodemus On Poems Books Three and Four, pp. I98-207.

8I. On initial and final titles at Herculaneum see G. Del Mastro, Titoli e annotazione bibliologiche nei papiri greci di Ercolano, Cronache Ercolanesi Suppl., 5 (Naples, 20I4).

82. Janko, Philodemus: On Poems Book One, pp. I2 I-I89; Delattre, La Villa des Papyrus, pp. I28-I30.

83. See Delattre, La Villa des Papyrus, pp. I I6, I 21, on the importance of this step. He advocates digital models too, but they are hard to manipulate.

84. Delattre relates how he twice thought his reconstruction was finished before it actually was: see La Villa des Papyrus, pp. I25-I27.

\section{Bibliography}

Angeli, A., 'Lo svolgimento dei papiri carbonizzati', Papyrologia Lupiensia, 3 (I994), 37-IO4

Blank, D.L., 'Reflections on Rereading Piaggio and the Early History of the Herculaneum Papyri', Cronache Ercolanesi, 29 (I999), 55-82

Blank, D.L., and Longo Auricchio, F., 'An Inventory of the Herculaneum Papyri from Piaggio's Time', Cronache Ercolanesi, 30 (2000), I 3 I-I 47

Booras, S. W., and Seely, D. R., 'Multi-Spectral Imaging of the Herculaneum Papyri', Cronache Ercolanesi, 29 (I999), 95-I00 
Capasso, M., 'Primo supplemento al Catalogo dei Papiri Ercolanesi', Cronache Ercolanesi, I9 (1989), I93-264

Capasso, M., Manuale di papirologia ercolanese (Galatina, I99I)

Capasso, M., Volumen: aspetti della tipologia del rotolo librario antico (Naples, I995)

Capasso, M., 'Per la storia della papirologia ercolanese III: il Piaggio a lavoro', in Bicentenario della morte di Antonio Piaggio, ed. by M. Capasso (Galatina, I997), pp. 6I-76

Chang, R.-L., Un dossier fiscal hermopolitain d'époque romaine (P. Stras. inv. gr. 897-8, 903-5, 939-68, 982-I000, Iого-I3, I9I8-29): édition et commentaire (IFAO, Cairo, forthcoming)

Del Mastro, G., 'Secondo supplemento al Catalogo dei Papiri Ercolanesi', Cronache Ercolanesi, 30 (2000), I 57-24 I

Del Mastro, G., Chartes. Catalogo Multimediale dei Papiri Ercolanesi (Naples, 2005)

Del Mastro, G., 'Il papiro Johannowsky: un papiro di Thmouis?', Aegyptus, 90 (2010), 23-36

Del Mastro, G., Titoli e annotazione bibliologiche nei papiri greci di Ercolano, Cronache Ercolanesi Suppl., 5 (Naples, 20I4)

Delattre, D., 'Philodème, De la musique: livre IV, colonnes 40* à Io9*', Cronache Ercolanesi, I9 (I989), 49-I43

Delattre, D., La Villa des Papyrus et les rouleaux d'Herculanum. La Bibliothèque de Philodème (Liège, 2006)

Essler, H., 'Bilder von Papyri und Papyri als Bilder', Cronache Ercolanesi, 36 (2006), I03-I 43

Essler, H., 'Rekonstruktion von Papyrusrollen auf mathematischer Grundlage', Cronache Ercolanesi, 38 (2008), 273-307

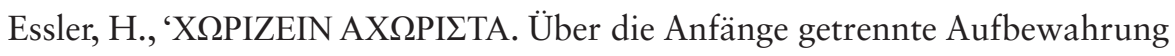
der Herkulanischen Papyri', Cronache Ercolanesi, 40 (2010), I73-189

Fackelmann, A., 'The Restoration of the Herculaneum Papyri and Other Recent Finds', BICS, I7 (I970), I44-I 45

Farese, R., 'Catalogo degli “illustrazioni” e degli interpreti', Cronache Ercolanesi, 29 (I999), 83-94

Fosse, B., Kleve, K., and Störmer, F.C., 'Unrolling the Herculaneum Papyri', Cronache Ercolanesi, I4 (I984), 9-I 5 
Gigante, M., ed., Catalogo dei Papiri Ercolanesi (Naples, 1979)

Hammerstaedt, J., 'Christian Jensen's and Wolfgang Schmid's Unpublished Herculanean Papers', in Proceedings of the XXVth International Congress of Papyrology, ed. by T. Gagos (Ann Arbor, 20IO), pp. 29I-298

Houston, G., Inside Roman Libraries (Chapel Hill, 20I4)

Janko, R., Philodemus: On Poems Book One (Oxford, 2000; ${ }^{2} 2003$ )

Janko, R., 'New Fragments of Epicurus, Metrodorus, Demetrius Laco, Philodemus, the "Carmen De Bello Actiaco" and Other Texts in Oxonian Disegni of I788-I792', Cronache Ercolanesi, 38 (2008), 5-95

Janko, R., 'Reconstructing (again) the Opening of the Derveni Papyrus', ZPE, I 66 (2008), 37-5 I

Janko, R., Philodemus On Poems Books Three and Four, with the Fragments of Aristotle On Poets (Oxford, 20II)

Janko, R., 'Parmenides in the Derveni Papyrus: New Images for a New Edition', ZPE, 200 (20I6), I-2I

Janko, R., Philodemus On Poems Book Two (Oxford). In preparation

Janko, R., with Blank, D.L., 'Two New Manuscript Sources for the Texts of the Herculaneum Papyri', Cronache Ercolanesi, 28 (I998), I73-I 84

Johnson, W. A., Bookrolls and Scribes in Oxyrhynchus (Toronto, 2004)

Kouremenos, T., Parássoglou, G. M., and Tsantsanoglou, K., The Derveni Papyrus (Florence, 2006)

Litta, V., I papiri ercolanesi II. Indice topografico e sistematico, Quaderni della Biblioteca Nazionale di Napoli IV. 6 (Naples, 1977)

McOsker, M., 'The Number of Papyrus Rolls Excavated from the Villa dei Papiri: Some Overlooked Evidence', Cronache Ercolanesi 46 (2016)

Longo Auricchio, F., 'L'esperienza napoletana del Davy', in Proceedings of the XIXth International Congress of Papyrology, ed. by A.H.S. El-Mosallamy (Cairo, I992), pp. I89-202

Nardelli, M. L., 'Ripristino topografico di sovrapposti e sottoposti in alcuni papiri ercolanesi', Cronache Ercolanesi, 3 (1973), I04-I I I

Obbink, D., Philodemus: On Piety Part I: Critical Text with Commentary (Oxford, I996)

Ohly, K., 'Die Stichometrie der Herkulanischen Rollen', Archiv für Papyrusforschung, 7 (1924), 190-220

Ohly, K., Stichometrische Untersuchungen (Leipzig, I928) 
Piquette, Kathryn E. forthcoming. 'Illuminating the Herculaneum Papyri: testing new imaging techniques on unrolled carbonised manuscript fragments', Digital Classics Online 3(2).

Schober, A., 'Philodemi De pietate pars prior', Cronache Ercolanesi, I8 (I988), 65-I 25 (diss. Königsberg, I923)

Scott, W., Fragmenta Herculanensia (Oxford, I 885 )

Sider, D., 'The Special Case of Herculaneum', in The Oxford Handbook of Papyrology, ed. by R.S. Bagnall (Oxford and New York, 2009), pp. 303-3 I 9

Travaglione, A., 'Incisori e curatori della Collectio Altera. Il contributo delle prove di stampa alla storia dei papiri ercolanesi', in Contributi alla Storia della Officina dei Papiri, iii, ed. by M. Capasso (Naples, 2003), pp. 87-I78

Travaglione, A., Catalogo descrittivo dei Papiri Ercolanesi (Naples, 2008)

Usener, H., Glossarium Epicureum, ed. by M. Gigante and W. Schmid (Rome, I977)

Vooys [Vooijs], C. J., Lexicon Philodemeum, i (Purmerend, 1934)

Vooys [Vooijs], C. J., and D. A. van Krevelen, Lexicon Philodemeum, ii (Amsterdam, I94I)

NOTE: This chapter was originally published with errors. A corrected version of the chapter was released on 30 October 20I7. The original errors are described below and have now been corrected:

- The omission of attribution to Kathryn Piquette of Reflectance Transformation Imaging (RTI)

- The incorrect Figure 9

- Missing figure captions 